\title{
リンガライズド・オクルージョンの \\ 有効性と人工歯咬合面形態に関して
}

小出馨* 旗手 敏"

\section{Lingualized Occlusion and the Occlusal Form of Artificial Teeth}

\author{
Kaoru Koide*, D.D.S., Ph.D., Satoshi Hatate**, D.D.S., D.M.Sc.
}

Investigations were carried out on three types of occlusal contact used in tissue-supported dentures: (A) full balanced occlusion, (B) lingualized occlusion of the type which maintains bilateral balance over a wide range, and (C) lingualized occlusion of the type which does not maintain bilateral balance over a wide range. Objective and quantitative comparisons were done on six factors: (1) jaw movements, (2) interposition of food, (3) food extrusion, (4) extent of antero-posterior guidance, (5) masticatory efficiency, and (6) electromyographs during mastication.

It was concluded that lingualized occlusion of the type which maintains bilateral balance over a wide range was superior for all of the factors. To further enhance this type of lingualized occlusion, investigations were carried out as to the ideal shape of the occlusal surface of the artificial teeth. This report discusses the eleven structural elements of the bladed teeth employing lingualized occlusion which we developed using knowledge obtained from these results. In addition, based on clinical results and evaluations, reports were made and the effectiveness was demonstrated on three clinical cases with different treatment methods where occlusal reconstruction was carried out using bladed teeth with lingualized occlusion.

\section{I はじめに}

世界の高齢化は加速し，この対応が人類の課題

*日本歯科大学新潟歯学部蒾科補経学教空第 1 講坐助教授

** 日本歯科大学新潟齿学部齿科補経学教室第 1 講座教授
となっているが，特に日本における高㱓者歯科臨 床で大きな比重を占めるのは，今後もやはり当分 の間，有床義歯による久損補綴治療であろう．欠 損補綴症例では, 通常, 雬の㳖失に追従したさま ざまな病的変化が生じており, もはや健全であっ た時点とは条件を異にし，咬合支持能力も著明に 
減衰している，現代日本人無歯靧患者を対象とし て臨床調査を行った小林ら ${ }^{1 \sim 4)}$ は， 65〜67歳です でに約半数の下顎㴿堤が, 平担かもしくは口腔底 よりも低い位置まで吸収しており，全体の $62.5 \%$ の患者は交叉咬合排列の適応症であることをあき らかにしている。次損補経治療の基本原則は, 残 存組織の保全と機能回復率向上の両立であり, 臨 床にあたっては, 残存組織を精査し, その支持能 力に応じた咬合を構筑することによってはじめて 残存組織が保護される。そして，その咬合は可及 的に機能回復率を高めるものでなければならな い。咬合に関しては，これまで多くの報告 ${ }^{5 \sim 10)}$ が なされてきたが, 本稿では, 教室の一連の研究結 果を通して, 残存組織保全と機能回復率向上の両 立性の観点から, 客観的に, いかなる咬合接触様 式が有床義歯症例にとって有利であるか, さらに どのような咬合面形態が有効であるかを探究し報 告する。

\section{II 有床義歯に付与する咬合接触様式として いかなる咬合接触様式が有利であるか}

教室では, 有床義画に付与する咬合接触様式に 関して一連の研究を行ってきているが，これまで に得られた知見 $\left.{ }^{11} 20\right)$ に基づき，残存組織保全と機 能回復率向上の両立性の観点から，一般的により 有利な咬合接触様式のあり方をまとめると表 1 亿 リンガライズド・オクルージョンの定義として示 す条件になる。すなわち，まず第 1 に咬頭嵌合位 において上顎臼歯舌側咬頭が均等かつ安定した状 態で下顎臼歯咬合面と 1 歯対 1 歯の関係で咬合接 触することである（図 1)。これは，咬合の舌側化

表 1 著者らの提晿するリンガライズド・オクルー ションの定義

リンガライズド・オクルージョンとは，咬頭嵌合 位において, 上顎臼菌舌側咬頭が下顎臼歯咬合面と 1 歯対 1 歯の関係で咬合接触し, 明確なセントリッ ク・ストップが確立されているとともに後方へのブ レーシング・イコライザーが付与されており，偏心 位においては広い範囲でバイラテラル・バランスが 保たれている咬合接触様式である.
を計ると同時に, 偏心位に括ける咬合接触滑走時 に上顎舌側咬頭が下顎の辺縁隆線部を越えること がなく，常に義霜の安定を保つためである．第 2 に中心咬合位ではもちろんのこと側方位において も後方へのブレーシング・イコライザーが付与さ れており，常に顎関節を保護する咬合接触様式で あること（図 2 )，第 3 に偏心位において広い範囲

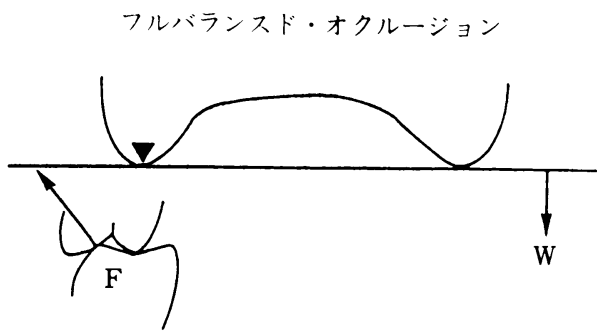

リンガライズド・オクルーション

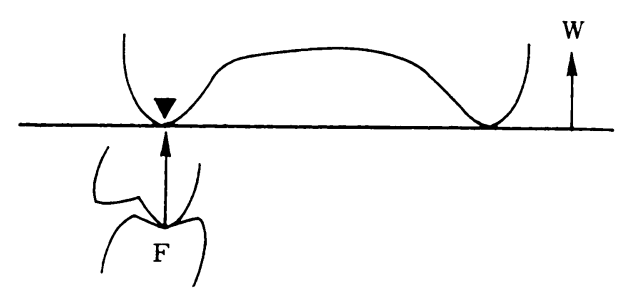

図 1 中心咬合位において，リンガライズド・オク ルージョンはフルバランスド・オクルージョ ンにみられる上下煩側咬頭どうし接触関係 が存在しない.したがって，同じ位置に人工 歯を配列しても，リンガライズド・オクルー ジョンでは, 力の加わる位置と力の加わる力 向の両面で舌側化が計れ，片側性テコ均衡を 保つ上できわめて有利である。

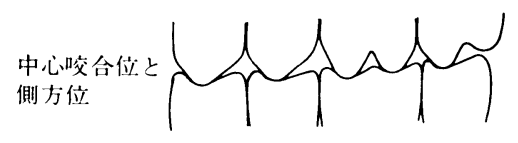

前 方 位

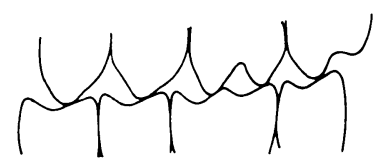

図 2 両側性平衡咬合のリンガライズド・オク ルージョンに拈ける臼霜部矢状断面図. 中心咬合位と側方偏心位では, 後方への ブレーシング・イコライザーが付与され て扣り，常に顎関節を保護する咬合接触 関係となっている。

第11巻 第 $2 \cdot 3$ 号 1990 
で両側性平衡（バイラテラル・バランス）が保た れていることである(図 3～5)，著者らは，この 条件を満たす咬合接触様式を「リンガライズド・ オクルージョン」として定義付けている。

一連の研究の対象とした 3 種の咬合接触様式 は，図6亿示すごとく，(A) Gysi5) の提唱する フルバランスド・オクルージョンで広範囲の両側 性平衡が保たれているもの，（B）著者らの提唱 するリンガライズド・オクルージョン15,16,20)で, 広範囲の両側性平衡が保たれているもの,

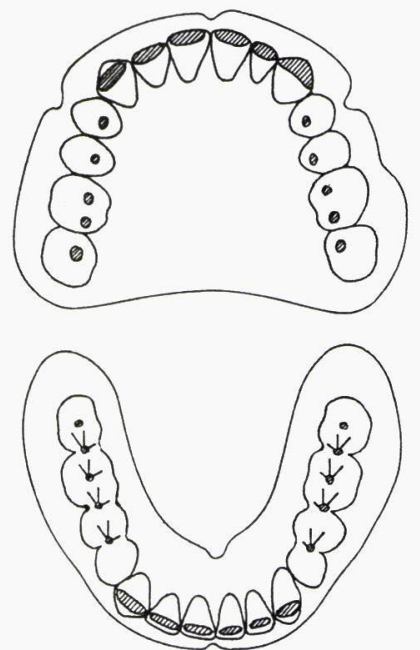

図 3 両側性平衡咬合のリンガライズド・ オクルージョンに拈ける咬合接触関 係。広い範囲でバイラテラルバラン スが保たれている。

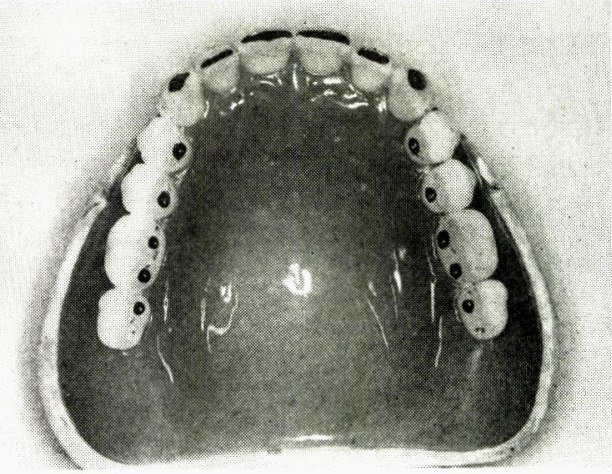

図 4 両側性平衡咬合のリンガライズド・オクルー

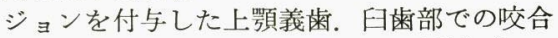
接触点は片側 5 力所, 両側で 10 力所付与する.

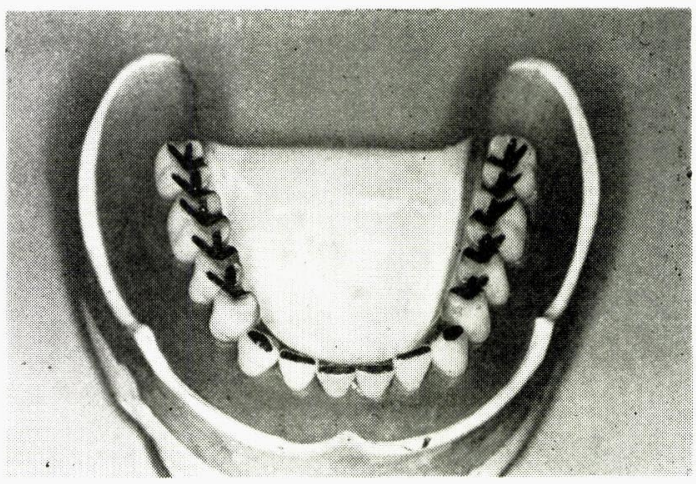

図 5 両側性平衡咬合のリンガライズド・オクルー ジョンを付与した下蕷義歯、咬合紙を介在さ せて前方扣よび左右側方への接触滑走運動を 行うと下顎のおの括ののオクルーザル・テー ブル上にゴシックアーチが描記される.

\begin{tabular}{|c|c|c|}
\hline & 中心咬合位 & 側方偏心位 \\
\hline $\begin{array}{l}\text { フルバランスド } \\
\text { オクルージョン }\end{array}$ & & \\
\hline $\begin{array}{l}\text { 屾側性平衡咬命の } \\
\text { リンガイ゙ } \\
\text { オクルージョン }\end{array}$ & & \\
\hline $\begin{array}{l}\text { 非両側性平衡咬合の } \\
\text { リンガライズド. } \\
\text { オクルージョン }\end{array}$ & & \\
\hline
\end{tabular}

図 6 研究の対象とした 3 種の咬合接触様式の構成 
表 23 種の咬合接触様式別にみた義歯床の安定性一顎運動による影響—

\begin{tabular}{|c|c|c|c|c|}
\hline & & $\begin{array}{l}\text { フルバランスド・ } \\
\text { オクルージョン }\end{array}$ & $\begin{array}{l}\text { 両側性平衡咬合のリンガラ } \\
\text { イズド・オクージョン }\end{array}$ & $\begin{array}{l}\text { 非両側性平衡咬合のリンガ } \\
\text { ライズド・オクルジョン }\end{array}$ \\
\hline 上顎義歯 & $\begin{array}{l}\text { 丕みからみた場合 } \\
\text { 動きからみた場合 }\end{array}$ & $\begin{array}{l}\times \\
0\end{array}$ & (1) & $\begin{array}{l}\times \\
\times \times\end{array}$ \\
\hline 下顎義歯 & $\begin{array}{l}\text { 歪みからみた場合 } \\
\text { 動きからみた場合 }\end{array}$ & $\begin{array}{l}\times \\
\times\end{array}$ & (2) & $\begin{array}{c}x \times \\
0\end{array}$ \\
\hline
\end{tabular}

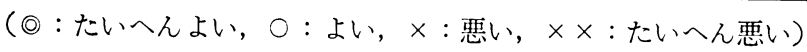

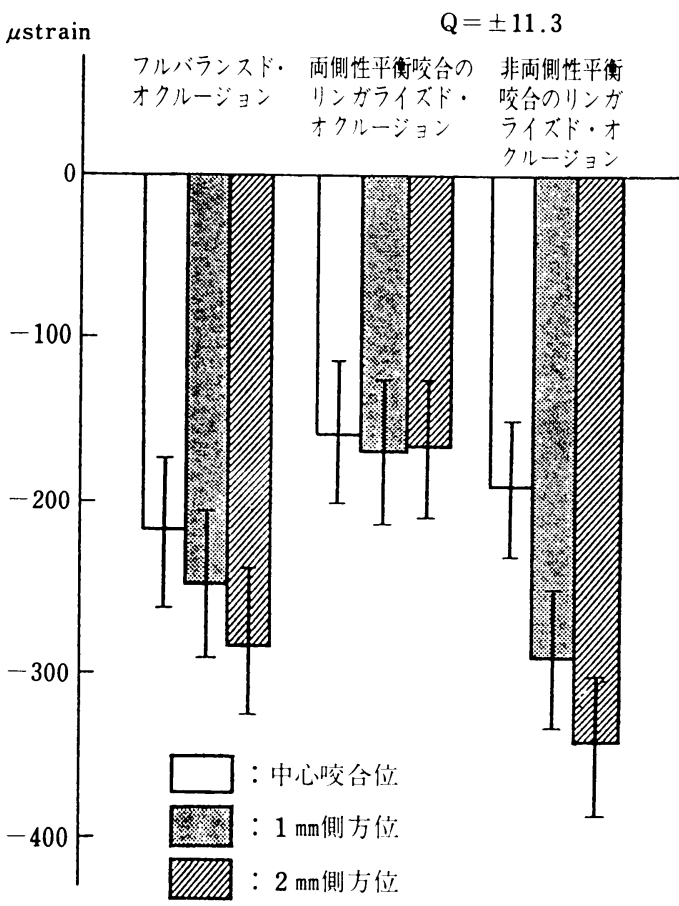

図 7 顎運動が上顎義系床の安定性に及ぼす影響

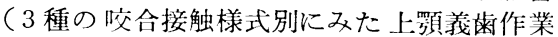
側煩側部に生じたひずみ量)

(C) Pound 5 $5^{7 \sim 9)}$ の提唱するリンガライズド・ オクルージョンで，広範井での両側性平衡は保た れていないもの（非両側性平衡咬合）の以上 3 種 である。これらの咬合接触様式を，(1) 顎運動と 義歯の安定性，（2）食品の介在と義歯の安定性, （3）食品溢出效果，（4）前後的誘導範囲と義歯の 安定性, (5) 咀嚼効率, (6) 筋電図学的評価, 以 上 6 つの要因別に比較した結果を報告する。

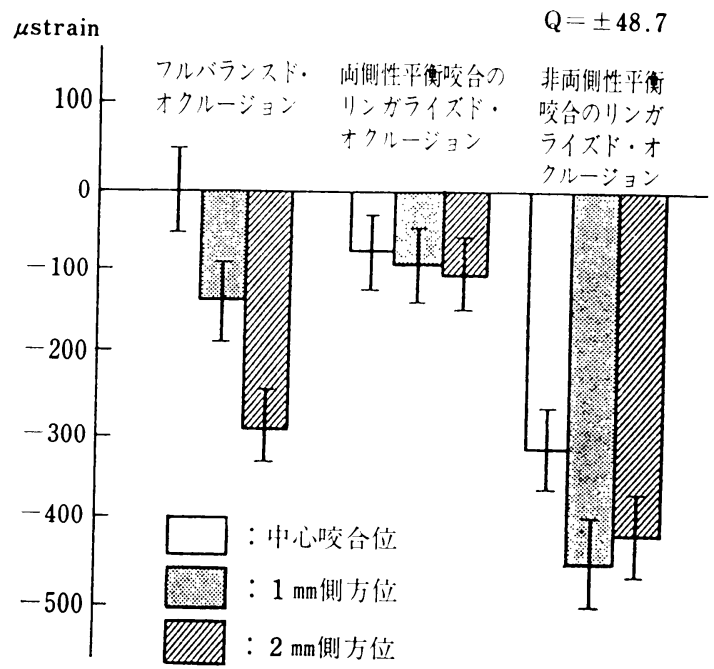

図 8 顎運動が下顎義歯床の安定性に及ぼす影響 （3種の咬合接触様式別にみた下顎義雨正中 部に生じたひずみ量)

\section{1. 顎運動が義歯床の安定性に及ぼす影響}

下顎運動が総義歯義画床の安定性に及ぼす影響 を義幽床に生じた移動量とひずみ量からシミュレ 一ター上で観察し，得られた結果を総合的に評価 して表 2 にまめて示す ${ }^{11)}$ 。両側性平衡咬合のリ ンガライズド・オクルージョンでは，上下顎義歯 ともに安定性がきわめて良好であったのに対し， フルバランスド・オクルージョンと非両側性平衡 咬合のリンガライズド・オクルージョンでは不良 であった．図７で示すグラフは上顎義歯，図８は 下䋶義歯に生じたひずみ量の変動を示す結果の 1 例である。

いずれも両側性平衡咬合のリンガライズド・オ クルージョンで下颚運動による影響が最も小さく 安定性に優れていることがわかる。図 9 は，義歯 
表 33 種の咬合接触様式別にみた義歯床の安定性一食品の介在による影響一

\begin{tabular}{|c|c|c|c|c|}
\hline & & $\begin{array}{l}\text { フルバランスド・ } \\
\text { オクルージョン }\end{array}$ & $\begin{array}{l}\text { 両側性平衡咬合のリンガラ } \\
\text { イズド・オジンシ }\end{array}$ & $\begin{array}{l}\text { 非両側性平衡咬合のリンガ } \\
\text { ライズドクシジン }\end{array}$ \\
\hline \multirow{2}{*}{ 上顎義歯 } & 雪みからみた場合 & $x$ & 0 & $x$ \\
\hline & 動きからみた場合 & $\times$ & ()) & $x$ \\
\hline \multirow{2}{*}{ 下顎義柬 } & 丕みからみた場合 & $\times$ & (2) & $x$ \\
\hline & 動きからみた場合 & $x \times$ & 0 & 0 \\
\hline
\end{tabular}

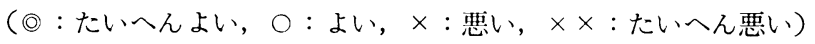

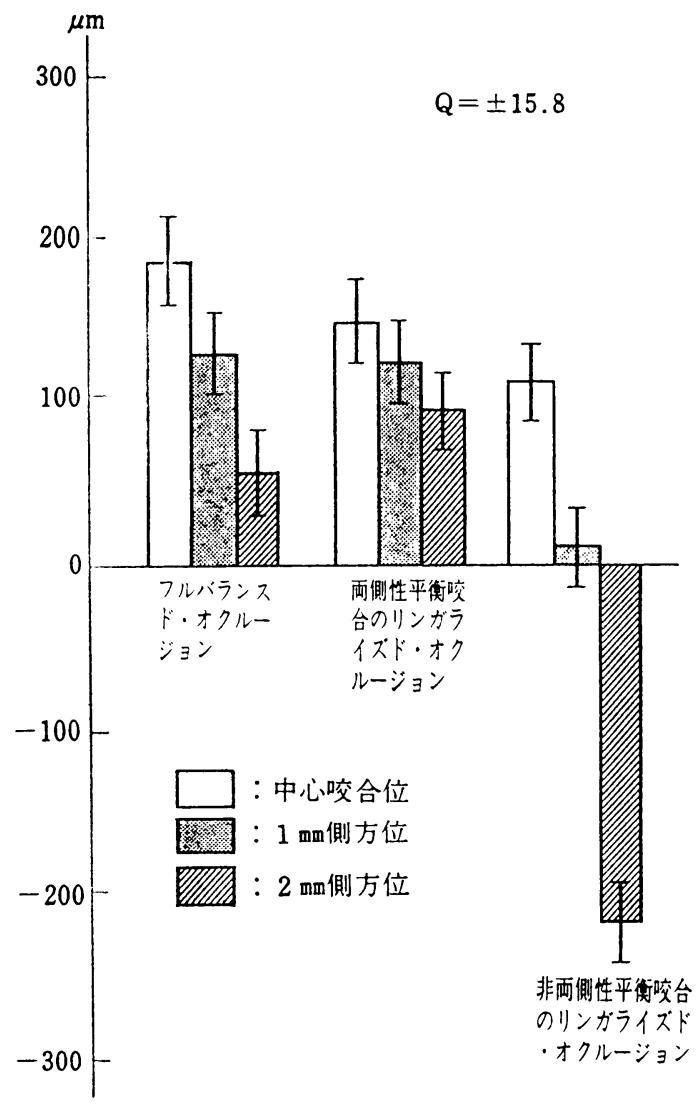

図 9 顎 運動が上頸義歯床の安定性に及ぼす影響 ( 3 種の咬合接触様式別に2た上顎義蔽平衡 側後方部に生じた移動量)

に生じた移動量の測定結果の 1 例であり,やはり 両側性平衡咬合のリンガライズド・オクルージョ ンで最も良好な安定性を示し，フルバランスド・ オクルージョンでは不良, 非両側性平衡咬合のリ ンガライズド・オクルージョンでは最も不安定で あった。この結果は, リンガライズド・オクルー ジョンにおいて両側性平衝を図 5 で示したように

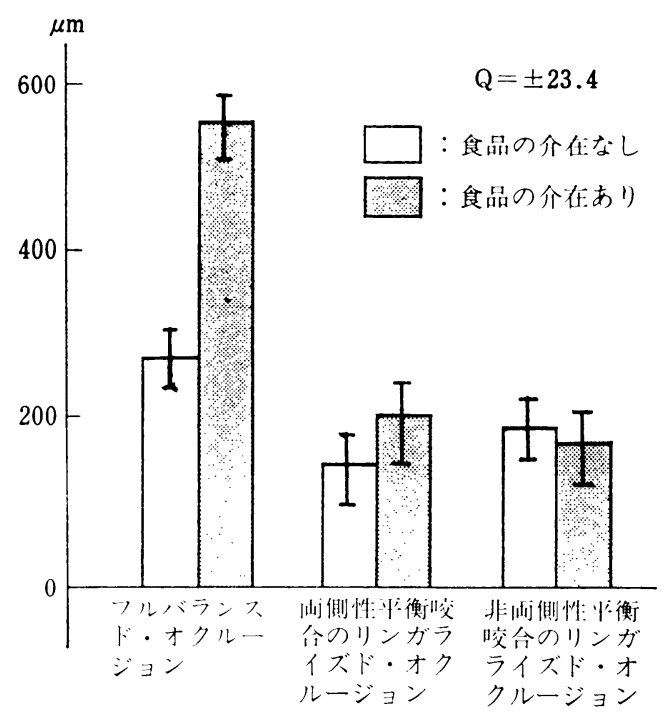

図 10 食品の介在が義歯床の安定性に及ぼす影響 (3 種の咬合接触様式別にみた下顎義歯作業 側後方部に生じた移動量)

広い範囲で保つことが，義霜の安定性を良好に保 つ上で有効であることを明示している。

\section{2. 食品の介在が義歯床の安定性に及ぼす影響}

作業側上下人工粦咬合面間に食品が介在するこ とが，義粟床の安定性に及ぼす影響を義霜床に生 じた移動量とひずみ量からシミュレーター上で観 察し，得られた結果を総合的に評価して表了にま とめて示す ${ }^{11)}$. 両側性平衡咬合のリンガライズ ド・オクルージョンでは上下顎義䛧ともに食品の 介在による影響が最も小さく安定性に優れてお り, 非両側性平衡咬合のリンガライズド・オクル ージョンでは安定性不良, フルバランスド・オク ルージョンでは上下顝義歯ともに最も不安定であ るといら結果が得られた。図10に示すグラフは結 果の 1 例であるが，特にフルバランスド・オクル 


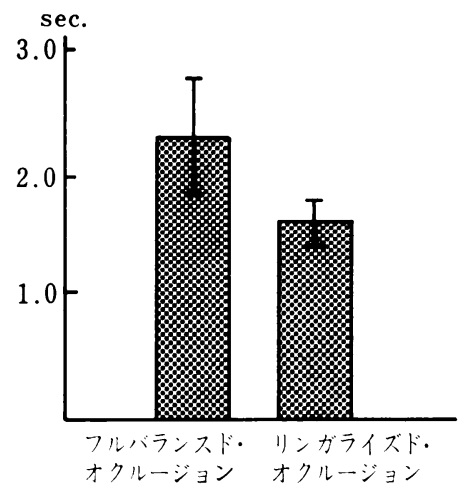

图 11 咬合接触様式別にみた疑似食品介在 条件下での閉口時間. リンガライズ ド・オクルージョンは, フルバラン スド・オクルージョンと比較して, 著明に閉口時間が短かく食品溢出効 果が高い。
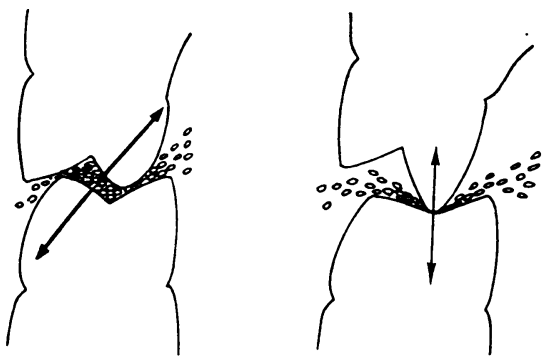

フルバランスド・オクルージョン リンガライズド・オクルージョン

図 12 フルバランスド・オクルーショョンでは, パッ クされた食品が人工歯の早期接触や咬頭干渉 と同様の影響を及ぼす。リンガライズド・オ クルージョンでは, 頓側へも舌側と同様に食 品が溢出するため優れた安定性を示す.

ージョンで食品が介在することにより義歯が大き く移動しているのに対し，リンガライズド・オク ルージョンは両者とも比較的良好な安定性を保っ ている，この差は, 食品溢出効果の差によっても たらされたものと考えられる。

\section{3. 食品湓出効果の比較}

義歯床の安定性や咀嚼効率に影響を及ぼす因子 として食品溢出効果があげられるが，図11は作業 側上下人工歯咬合面間に疑似食品を介在させ，中 心咬合位までの閉口時間をシミュレーター上で計 測することにより，咬合接触様式間の食品溢出効

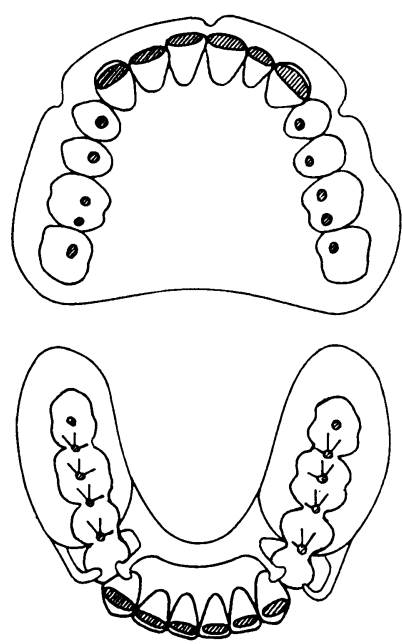

図 13 上顎が総義歯で下顎が両側性遊 離端義雪といら条件下で構成し たリンガライズド・オクルーシ ョンの咬合接触状態。

果を比較した結果である。フルバランスド・オク ルージョンに対し，リンガライズド・オクルージ ョンは, 著明に閉口時間が短く,より食品溢出効 果が高い傾向を示した。これは，フルバランス ド・オクルージョンが図12に示すような上下人工 歯の両面均衡接触咬合であるため咀嚼時飞食品が パックされてしまらことに起因する。このパック された食品が人工歯の早期接触あるいは咬頭干渉 と同様な作用を及ぼすため，前項で示したように 義雪の安定性は著しく不良となる。一方，リンガ ライズド・オクルージョンでは, 頓側方向へも舌 側方向之同様に食品が溢出するため, 食品溢出効 果は高く，義歯の安定性を良好に保つことができ る.

\section{4. 前後的誘導䉪囲が鈎歯の負担と義歯床の安定性 に及ぼす影響}

次に，上顎が総義歯，下顎が R.P.I. とリンガ ルバーによる両側遊離端義歯といら条件のもと で，前後的咬合誘導範囲が鉤歯の負担と義歯床の 安定性に及ぼす影響をシミュレーター上で観察し $た^{12)}$ (図13)，図14で示すグラフは，結果の 1 例で あるが，最後方歯 $\frac{7}{7} \mid \frac{7}{7}$ を中心咬合位のみ咬合接 触させ，偏心位では disclusion させる条件が，鉤 


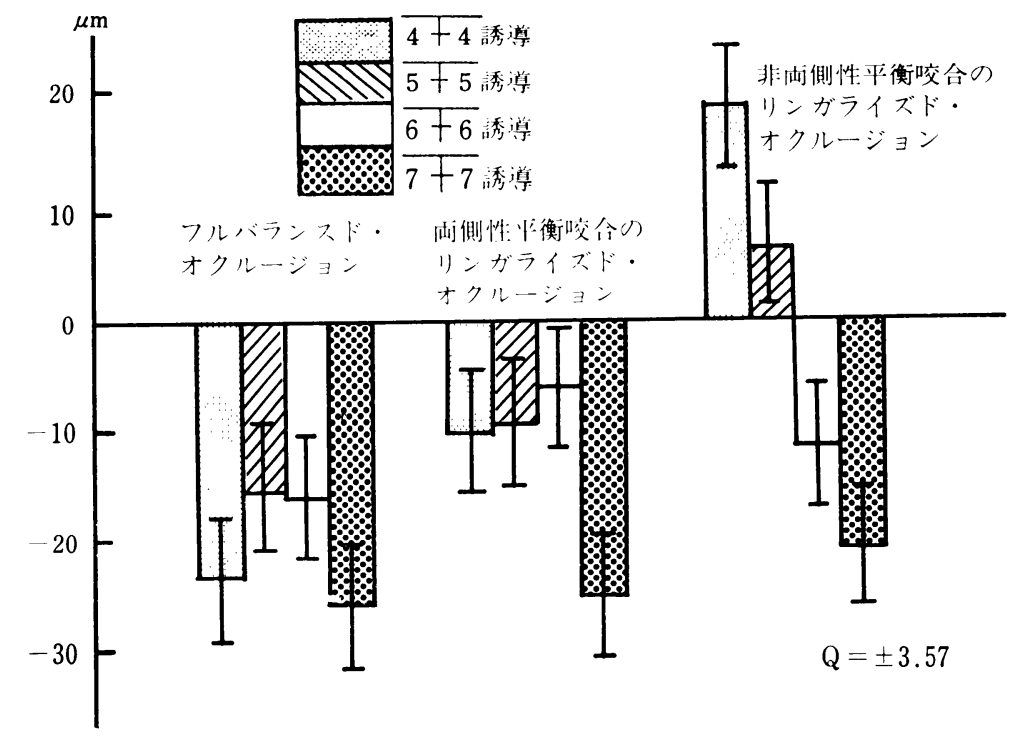

図 143 種の陸合接触様式別にみた作栄側鈎来函根部の煩、側方向への移動量 之㷙後的咬合誘導範囲.

歯の負担压を最も軽減させるとともに，上下顎義 米の安定性もより良好に保つことが示された。し たがって, 総義䊩に抢いても, 阿側性平衡咬合の リンガライズド・オクルージョンは前後的誘導範 囲を $\frac{6+6}{6+6}$ とし $\frac{7 \mid 7}{7} \mid 7$ は偏心位で disclusion させる ことにより，義歯の安定性を良好に保つことがで きるものと考えられる。

\section{5. 咀融効率}

3 種の咬合接触様式間で咀嚼効率を比較する日 的で，6名の総義歯装着者におのおの 3 種の咬合 接触様式を順次付与してピーナッッ咀嚼を行わ せ, Manly, Braley の方法に従って咀嚼值を測定 した ${ }^{13,20)}$. その結果, 図15のグラフに示すように フルバランスド・オクルージョンと网側性平衡咬 合のリンガライズド・オクルージョンの間に差は 認められず，いずれも高い值を示したが，非両側 性平衡咬合のリンガライズド・オクルージョンで は著明に低い值を示した。これは，两側性平衡 を広い範囲で付与することが咀嚼を効果的に行ら 上で重要であることを示唆するものである。ま たリンガライズド・オクルージョンでは, 図16 に示すように咬合接触面積が小さいため, 上䫇吉

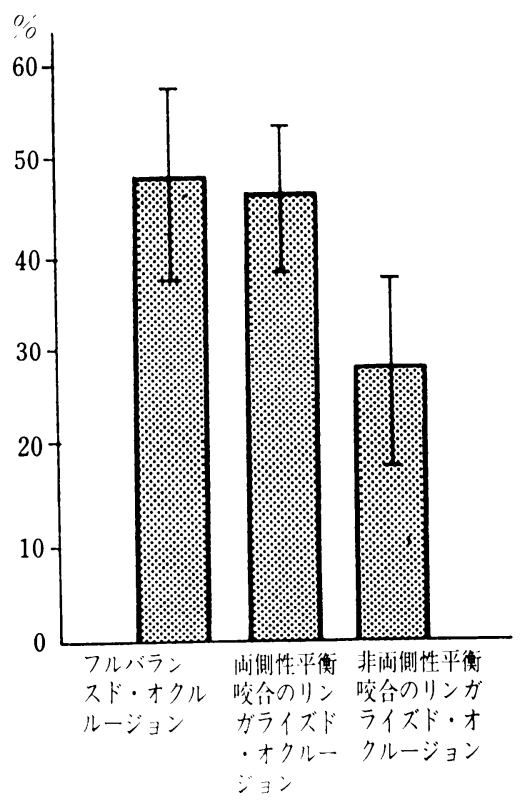

図 153 種の咬合接触様式別にみた咀啲値 (Manly, Braley の方法). フルバラ ンスド・オクルージョンと両側性平 衡校合のリンガライズド・オクルー ジョンでは, いずれも高い值を示し たが，非活側性平衡咬合のリンガラ イズド・オクルージョンでは低い值 を示した。 


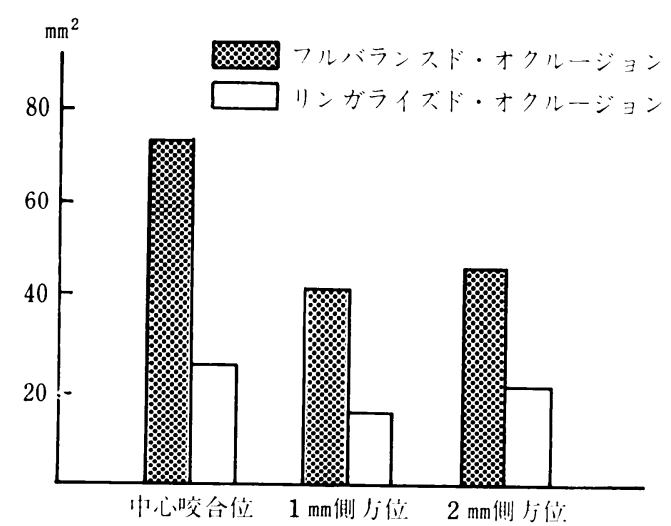

図 16 咬合接触様式別にみた各顎位における 咬合接触面積.

側咬頭に加わる単位面積あたりの咬合圧が高めら れ，咀嚼時に大きな食品剪断力を発揮することと なる.したがって，年齢的にも機能的にも咬合 力の減衰が避けられない有床義歯装着者が, ビー フ・ステーキやサキイカ, タクアンといった両面 均衡接触咬合では破砕しにくい食品でも, 雨側性 平衡咬合のリンガライズド・オクルージョンであ れば咀嚼できるようになり，食べられる食品の範 囲が大幅に広がることになる。

\section{6. 筋電図学的評価}

咀嚼がいかに円滑であるかを 3 種の咬合接触様 式間で比較する目的で，4名の総義歯装着者おの おのに 3 種の咬合接触様式を順次付与し, 各種食 品（ピーナッッ，カマボコ, サキイカ）を咀嚼さ せ, 筋活動椂相を観察した ${ }^{13)}$. 図17のグラフは, 咬合接触様式別に各咀嚼段階におけるサイクル・ タイムの変異係数を示している。咀嚼初期, 中 期, 後期々して咀嚼全期のいずれの咀嚼段階にお いても両側性平衡咬合のリンガライズド・オクル ージョンで最小の值を示しており, 最もリズミカ ルでスムーズな咀嚼が行われていることが示され た。 また, 被験者の感想は, いずれの被験者も両 側性平衡咬合のリンガライズド・オクルージョン が，どんな食品でも食べやすく一番具合いが良い 満足できる咬み合わせであると述べている。

本稿では, 一連の咬合接触様式に関する研究で 28

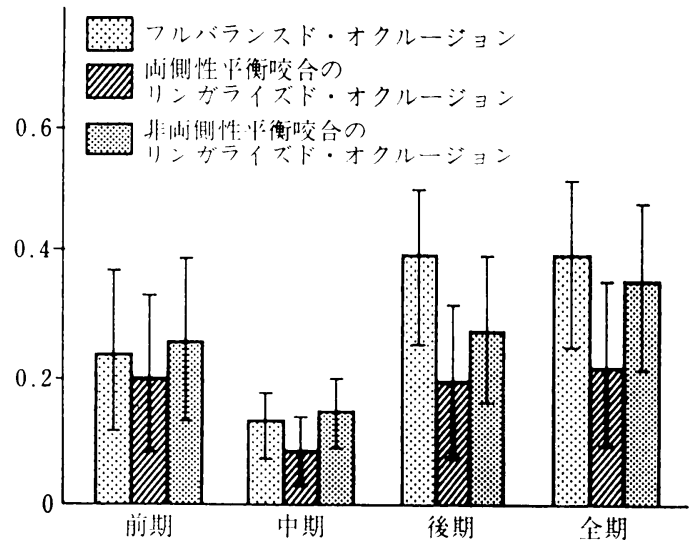

図 173 種の咬合接触様式別にみた食品咀嚼時の作 業側側頭筇筋電困に㧍ける cycle time の変 異係数. 两側性平衡咬合のリンガライズド・ オクルージョンが，いずれの咀嚼段階におい ても最小の値を示しており, 最も円滑な咀畄 が行われていることがわかる.

得られた知見の一部を示したが，これらにより有 床義歯に付与する咬合接触様式として, 現時点で は表 1 に示した条件のリンガライズド・オクルー ジョンが有利であるという結論に至っている。そ こで, 次にこの様式のリンガライズド・オクルー ジョンの有効性を最大限に生かすために, 人工歯 の咬合面形態はいかにあるべきかを探究する。

\section{III リンガライズド・オクルージョンのた めの人工歯咬合面は, どのような形態 が有利か}

有休義雨に付与する咬合接触様式は, 広範囲で 両側性平衡咬合が保たれているリンガライズド・ オクルージョン（表1）が, 現時点では, 残存組 織保全と機能回復率向上の両立性の観点から, 上 り有利であるという結論を得たが, 次にこのリン ガライズド・オクルージョンを構成する人工歯の 咬合面形態に関して, 著者らは従来の既成概念に とらわれることなく, 人工歯の各構成要素ごとに 検討を重ね、リンガライズド・オクルージョン用 ブレード・ティースを開発した ${ }^{14,16)}($ 図18，19）.

現在まで 9 年にわたり, 実際に多数の症例でこ のリンガライズド・オクルージョン用ブレード・ 


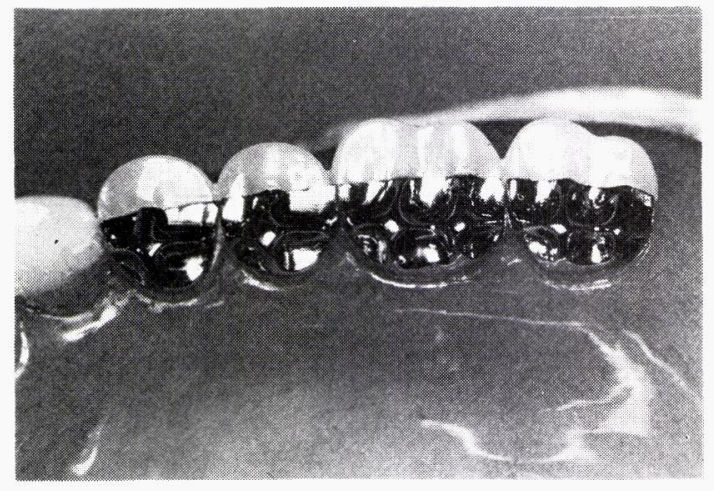

図 18 著者らの考案したリンガライズド・オクルー ション用ブレード・ティースの上顎人工㐘咬 合面観.

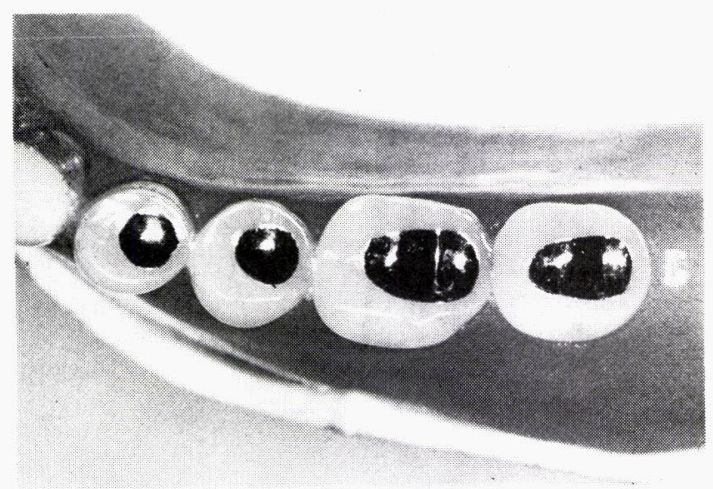

図 19 下顎人工歯咬合面観

ティースを臨床応用し，いずれも良好な成績をお さめている.

本稿では, この人工窲の特徴を, (1) 舌側咬頭 のブレード化とその有効性，（2）頓側咬頭と審美 性，（3）ブレードの設置角度，（4）人工歯の連結 そその有効性，（5）ブレード部基底面の広さ， （6）ブレードの高径, (7) ブレード起始部の形 態，（8）前方運動時の接触滑走部，（9）下顎人工 歯のオクルーザルテーブル，(10）ブレード部の 断面形態とレジンとの結合，（11）ブレードの材 料, 以上11項目の構成要素ごとに示す。また，こ のリンガライズド・オクルージョン用ブレード・ ティースの臨床応用例を臨床成績の評価を交えて 報告する。

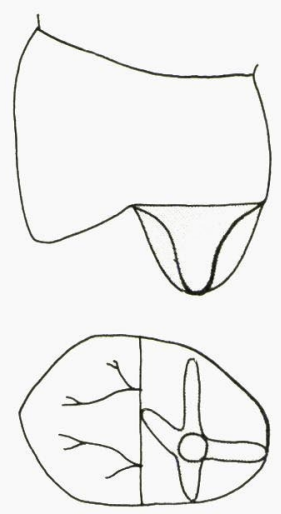

図 20 舌側咬頭は, 前後方向に植立さ れた 1 枚と左右方向に植立され た 2 枚, 計 3 枚のブレードによ って構成されている。

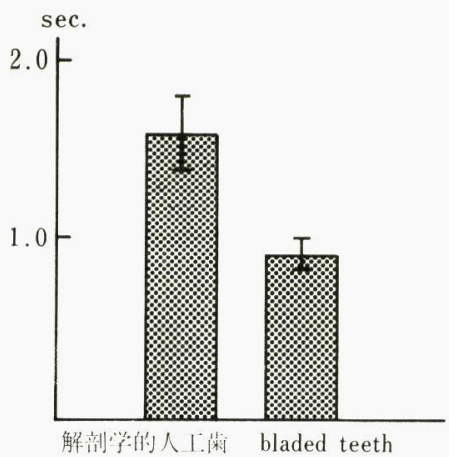

図 21 人工雨の咬合面形態別にみた疑似食 品介在条件下での閉口時間. リンガ ライズド・オクルージョン用ブレー ド・ティースでは, 解剖学的人工歯 と比較して, 著明に食品溢出効果が 高い.

\section{1. 上顎臼歯舌側咬頭のブレード化とその有効性}

これまでに非解剖学的咬合面形態を有する人工 米は数多く紹介されているが,なかでも, Sosin'21), 阿部22 24) による S-A Bladed Metal teeth と Levin ${ }^{25)}$ にる Levin Bladed teeth は, bladed teeth の広範な有効性と将来性を示するので，著 者らも多くの示唆を与光られた。

上䫟臼歯舌側咬頭をすべてブレード状とするこ とは, 筊合接触面積が小さく, 食品溢出効果が高 いといらリンガライズド・オクルージョンの長所 をさらに高めるものである。つまり，上靧舌側咬 
解剖学的人工歯

L.O. 用ブレード・テ1

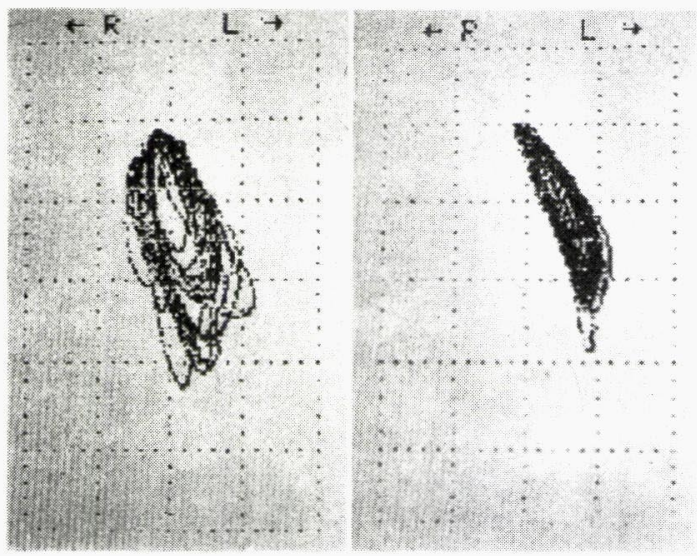

図 22 人工歯置換前後のピーナッッ咀嚼時の下䪽切 歯点咀嚼運動経路（前頭面投影・第 5 15 万 トローク)

頭に加わる単位面積当りの咬合圧を増大させ, 乙 かも図20に示すように1つの舌側咬頭を構成する 3 枚のブレードの間隙によって食品の溢出効果も 飛躍的に高められ，咀嚼時にきわめて大きな剪断 力を発揮することとなる。

図21は，作業側上下人工歯咬合面間に疑似食品 を介在させ，中心咬合位までの閉口時間をシミュ レーター上で測定することにより，リンガライズ ド・オクルージョンを解剖学的人工歯で構成した 場合と専用のブレード・ティースで構成した場合 の食品溢出効果を比較した結果である。専用のブ レード・ティースの方が解剖学的人工歯よりも著 明に閉口時間が短かく食品溢出効果が高い傾向を 示した.

このように, 小さな咬合力で十分に食品を破砕 し咀嚼できるため, 患者は機能時に過大なかみし めを行う必要がなくなり, 床下組織の負担も軽減 され, しかも咀嚼できる食品の範用も飛躍的に広 がる、さらに, 通常の解剖学的人工歯をこのリン ガライズド・オクルージョン用ブレード・ティー スに置換すると，頻繁なグラインディングを行わ なくとも楽に十分な咀嚼が行えるため, 咀嚼パタ ーンの変化が生ずる ${ }^{17,18,26)}$. 図22は, 局部床義歯 患者の人工歯を, 解剖学的人工歯からリンガライ ズド・オクルージョン用ブレード・ティースに置

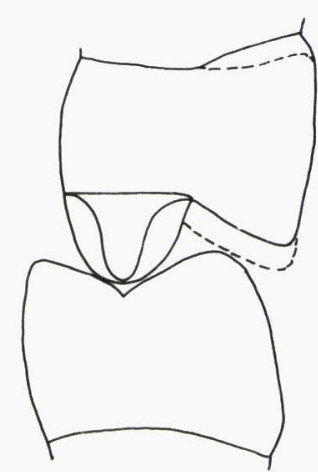

図 23 上龥の第 2 小曰歯から遠心側人 工歯の䫅側咬頭と舌側咬頭の位 置関係

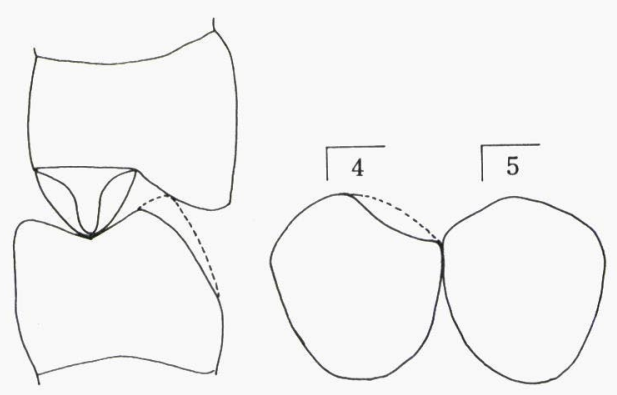

図 24 下罰第 1 小目㐘煩側峧頭の形態

換し, 術前と術後 1 カ月に和けるピーナッッ咀嚼 時の下顎切歯点咀嚼運動経路 (前頭面投影・第 5 〜15 ストローク)を Myotronics 社製 Mandibular Kinesiograph (MKG) により記録したものであ る.ブレード・ティースへの置換後では, 咀嚼経 路の改善傾向が認められ, 咀嚼パターンもチョッ ピングタイプに近付く傾向を示した。 このこと は, 機能時に打ける義歯の安定性をさらに高める 結果となり，床下組織の負担軽減の上からもきわ めて有利である。

\section{2. 煩側咬頭と審美性}

ブレードの範囲は舌側咬頭部のみで, 煩側咬頭 は症例に応じて滑走間隙量の微調整が可能なよう にレジンにて製作されている。 また，この煩側咬 頭には解剖学的形態が付与されて特り, 色調も歯 冠色をしているため, 審美性にも優れている。ま た，図23に示すように䫅側歯冠長は解剖学的平均 


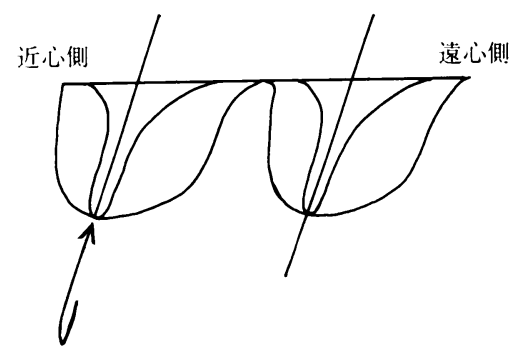

图 25 矢状面上にみるブレードの設置角度は, 下顎の閉口角度と協調している。

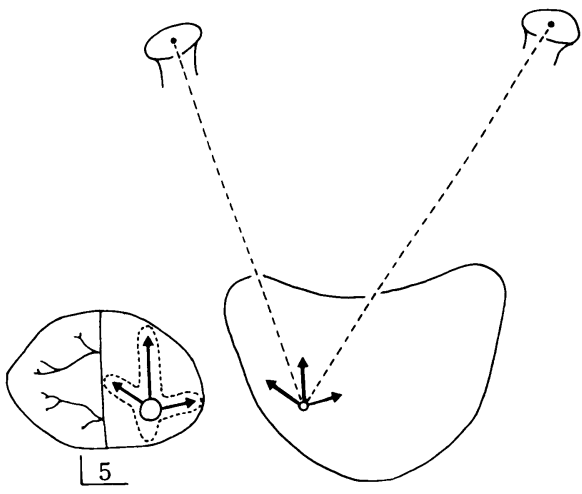

图 26 咬合平面上にみるブレードの設置角度

值としているが，第 2 小臼歯から遠心側人工歯の 頓側咬頭頂の位置は舌側咬頭に対して, 解剖学的 平均值よりも滑走間隙量分の $2 \mathrm{~mm}$ がすでに低位 となっており，従来の人工歯を使用した際に行っ ていた大幅な形態修正が不要である。上顎の第 1 小臼歯に関しては，前歯部からの審美的な連続性 を重要視し，頓側咬頭頂の位置を解剖学的平均值 とする一方，図24に示すように，下顎第 1 小臼㭃 遠心咬頭隆線部を三日月状に削除した形態とする ことにより，滑走間隙を確保している.

\section{3. ブレードの設置角度}

ブレードの矢状面上にみる設置角度は，図25に 示すように，咀嚼時における下顎の閉口角度と協 調している。また，咬合面上にみるブレードの設 置角度は，図26に示すように，各下顎人工歯咬合 面上に下顎の偏心運動により描かれる平均的なゴ シック・アーチの描記される角度と協調してい る。これらにより，食品剪断効果をきわめて効率 よく発揮することができる。また，各ブレード

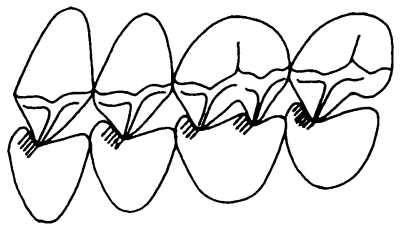

図 27 リンガライズド・オクルージョン用 ブレード・ティースでは，第 1 小目 歯から第 2 大臼歯まで 4 本が所定の 角度で連結されている.また, 下㖽に はブレーシング・イコライザーの確 立が容易な形態が付与されている。

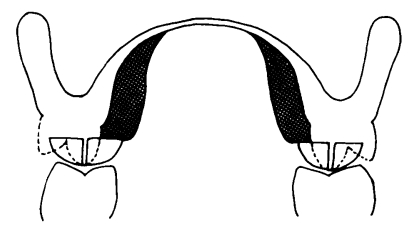

图 28 ブレード基底面の広さによる影響 ブレード基底面が広過ぎると舌房 を大きく侵害することになる。

は，下顎人工雨のオクルーザル・テーブル上へ食 品を把持して運ぶ作用を発揮し，これによっても 効率の良い食品の細小化が部れる。

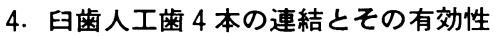

前述のように, 各ブレードの設定角度は, 下顎 の誘導部分との接触滑走がスムーズに行兄，高い 咀嚼効果が得られるように考慮して，3次元的に 顎機能と調和させてある。したがって，人工雨排 列にあたっては，1歯ごとの排列角度の設定をこ の基準に従って行わなければならない。また，上 下煩側咬頭間には所定の滑走間隙が付与されてい るため, この要素からも一歯ごとに滑走間隙を確 認しながら 3 次元的位置付けを行わなければなら ず，容易な操作ではない，そこで，このリンガ ライズド・オクルージョン用ブレード・ティース は，図27に示すごとく上下とも第 1 小臼歯から第 2 大臼歯まで 4 本をあらかじめ所定の角度に設定 して連結した。すなわち，臼雨人工歯部は全簤で 4 ブロックからなり，排列の際には前後的咬合平 衡が保てるように咬合平面傾斜度のみ調整すれば よく，きわめて短時間で容易に，乙かも適確に排 

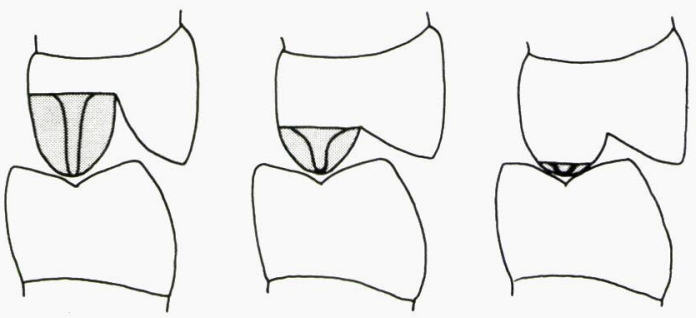

図 29 ブレードの高径による影響
A

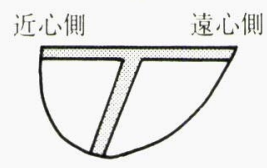

再側

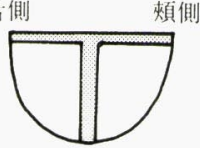

図 30
B
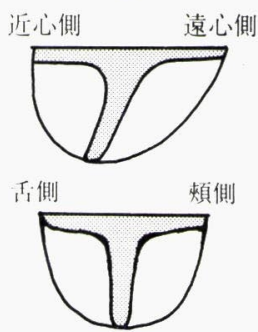

煩側
ブレード起始部の形態、 B は Aよりも食

品が停滞しにくく食品溢出効果が高い.

列操作を完了することができる.

\section{5. ブレード部基底面の広さ}

この人工歯の各ブレード部基底面の面積は, そ れぞれの舌側咬頭の解剖学的平均值とし, 局部床 義歯へも容易に応用できるようにした。もし，ブ レードの寸法が大き過ざると，対合歯が残存して いる場合に応用範囲がせばまるばかりでなく， 図28に示すようにブレードの咬頭頂から舌側縁ま での寸法が大きくなり，その分，口蓋側人人工歯 が張り出して，舌房を大きく侵害することとな る. 舌房の侵害は, 嘔吐反射の誘発, 舌の損傷の みならず，わずか $1.5 \mathrm{~mm}$ の舌房侵害によって も, 、わゆる顎関節症之同等の咀嚼機能障害を生 じさせることが筋電図学的にあきらかにされて拉 り ${ }^{27)}$, 慎重に対応しなけ玌ばならない。

\section{6. ブレードの高径}

ブレードの高径を高くする程, 食品溢出効果も 高まるが，一定の高さ以上になると，その高さに 応じて基底部の面積を拡大しないとブレード部の 形態的調和をとることが困難になってくる。しか し, 前述のごとくブレード部基底面の面積は解剖

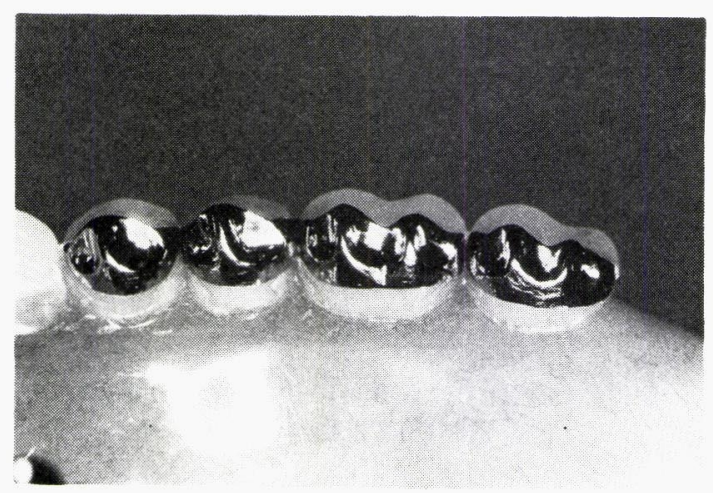

図 31 上顎人工歯の舌側面形態

学的平均值を大きく越えて拡大すると，舌房を侵 害し種々の問題が生じてくる。また, ブレードの 高径を大きくするにつれ，煩側咬頭との連続性に 問題が生じてきて審美性を損なうことにもなる。 しかも，図29に示すよらに煩側咬頭内斜面が急傾 斜となり，義歯床を不安定にする因子ともなる. これらの条件によりブレードの高径を割り出す と， $3 \mathrm{~mm}$ が上限である。ブレードの高径が大き 過ぎる場合には，イクラや米などのように，食品 によって上下雨列間に把持しにくく，らまく咀嚼 できない食品が生じてくる。一方，ブレードの高 径が小さ過ぎると，図29に示すように，接触面積 が小さく, 食品溢出効果が高いといらブレードの

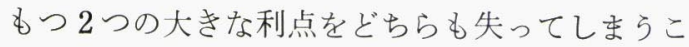
とになり, 支持組織への負担軽減効果が小さく, 咀嚼効率の低下にもつながるので注意を要する.

\section{7. ブレード起始部の形態}

ブレード起始部の形態は, 図30に示すよらにブ レード先端部からブレード部基底面への自然移行 形態となっている。これは，食品が上下咬合面間 に停滞し咀嚼効率を低下させる要因となるブレ一 ド起始部の隅角をとり除き，食品溢出作用を高め る効果があり，ブレードの高径がさ活ど大きくな いにもかかわらず食品が停滞することがなく，高 い咀嚼効率を導き出している。また，陷四した不 要な線角执よび点角が存在しないため, 食物残椬 の停滞を防止でき，義歯を清潔に保つらえでも有 利である。

また，図31に示すようにブレード基底部舌側縁 


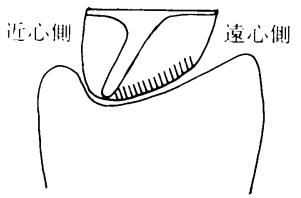

図 32 前後方向に設置されたブレード の側面形態. 前力運動時に接触 滑走する部分は円弧が大きい。

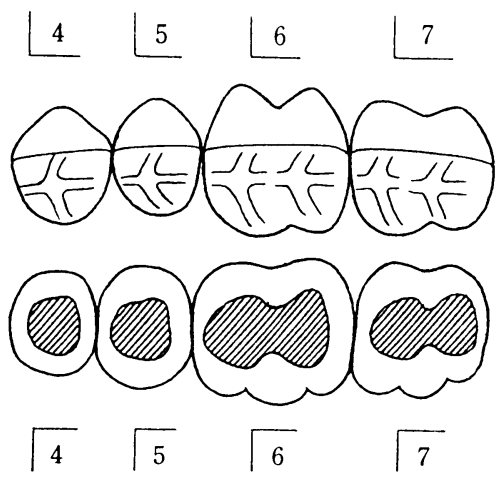

図 33 下顎人工粀咬合面は機能運動範四を 金属に置換する。

の凸隅角にも丸みを与光，舌の損傷を防止してい る。

\section{8. 前方運動時の接触滑走部}

前方運動時に，下顎人工歯咬合面と接触滑走寸 るブレード部分の彎曲度を小さくすることによっ て，図32に示すようにこの部のブレードの円弧を 大きく設定している。このことにより，前方運動 時に症例に応じたスムーズな接触滑走運動が営め る.

\section{9. 下顎人工歯のオクルーザル・テーブル}

下顎人工歯のオクルーザル・テーブルには，列 溝を付与せずに平滑な罒状形態を与えた。下顎の 前方および左右側側方への偏心運動時には，上顎 人工歯の舌側咬頭頂部の咬合接触点が下濒人工米 の辺縁隆線を越えることがない形態に上下人工歯 を設計しているため，きわめて円滑な咬合接触滑 走運動が可能であり，機能時に打ける義霜の推進 現象を効果的に抑制できる。また，健全な顎関節 の状態を維持していくためには, 後方へのブレー

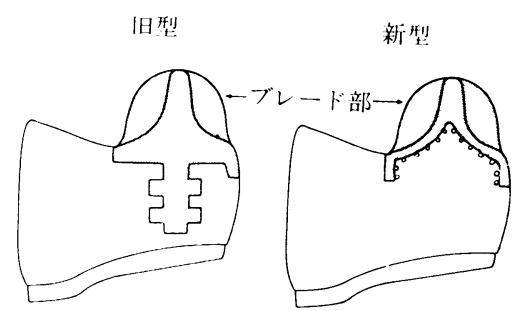

図 34 ブレード部の断面形態

シング・イコライザーが中心咬合位と左右側側方 偏心位で確立されていなければならないが，この 人工歯には，わずかな咬合調整によって症例に応 じたブレーシング・イコライザーを確立できる形 態が付与されている（図27）.

下顎人工歯はレジンで製作されているが，義歯 調整完了後, 図33に示すよらにオクルーザル・テ ーブルの機能運動範囲を金属に置換し，耐磨耗性 を向上させる。

\section{0. ブレード部の断面形態とレジンとの結合}

ブレード部の断面形態は, 図34に示すように, 中空性でブレードの先端部分が最も厚く設計され ている。これにより軽量化を計ると同時に経年的 咬耗に刘応している。 また，ブレード部内面には 全面に保持形態が付与されており，レジン部との 連結は強固である。旧型では連結部分がレジン内 へ深く埋入されていたのに対し，新型では金属部 分がレジンを包み込んでいるため, 結合も強固で あると同時に，症例に応じて米冠長を短かく調整 して使用することも可能である.

\section{1. ブレードの材料}

ブレードの材料としては, 生体への為害作用の 少ないことが必須条件であるが，本人工歯には， 金合金タイプIVで製作されたものとコバルト・ク ロム合金で製作されたものとの 2 種類があり，症 例に応じて使い分けている。

以上，リンガライズド・オクルージョン用ブレ ード・ティースの各構成要素について述べたが, 次にこの人工歯により著者らの提唱するリンガラ イズド・オクルージョンを構成した臨床例を供覧 する。このリンガライズド・オクルージョンは, 


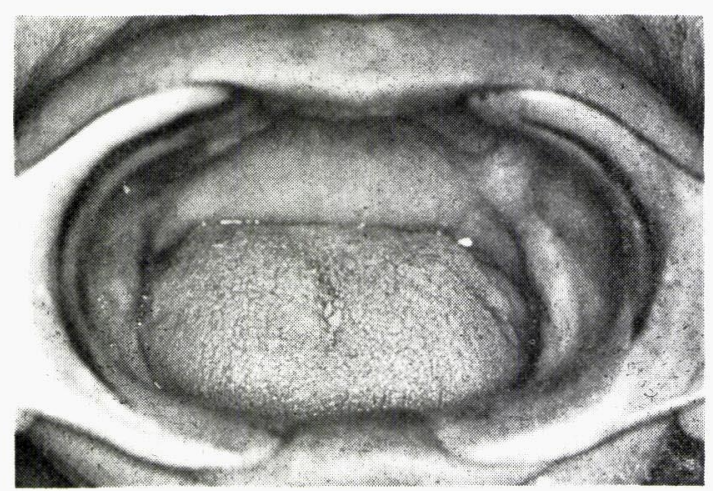

図 35 症例 $1 ：$ 術前の口腔内所見

上下顎ともに無歯顎で高度の吸収状態を示す。

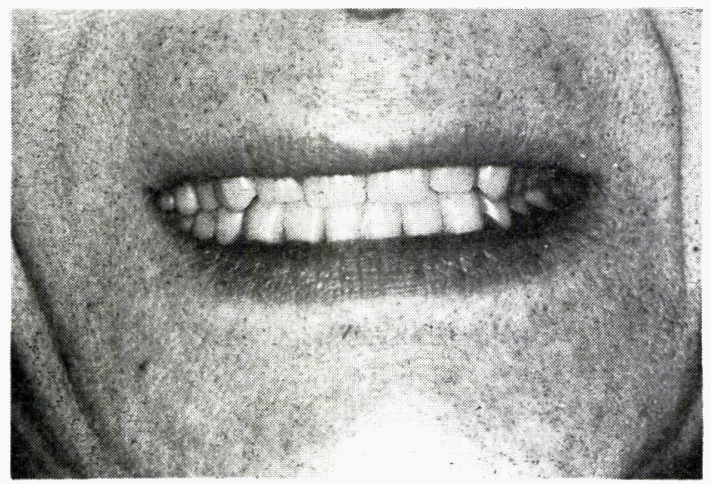

図 36 症例 $1 ：$ 術後所見

総義歯による補緅処置を施行した。

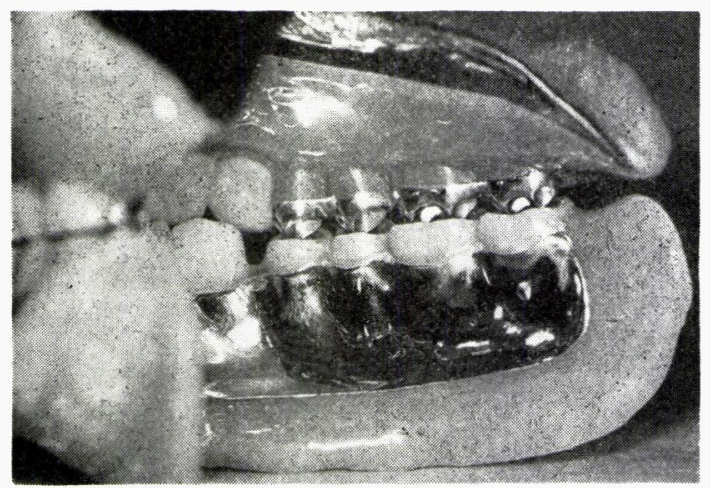

図 37 症例 1：リンガライズド・オクルージョン 用・ブレード・ティースを応用して著者らの 提唱するリンガライズド・オクルージョンを 付与した。

一般的な症例飞幅広く応用可能で高い有効性が認 められているが17,18), 本稿では補緅症例の中でも 特に難症例とされるものをあ劣てとりあげた。

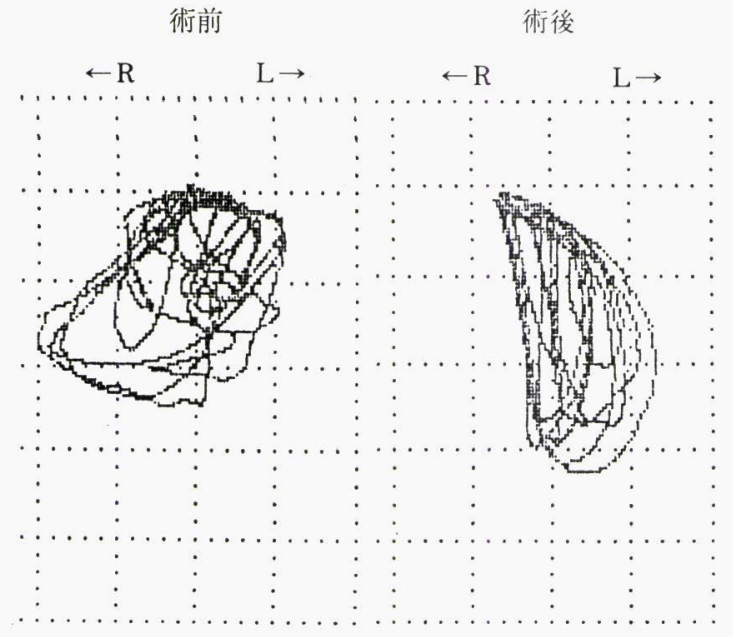

図 38 症例 1 ：術前と術後 1 カ月における咀㘉運動経 路記録（前頭面投影・第 $5 \sim 15$ ストローク）。

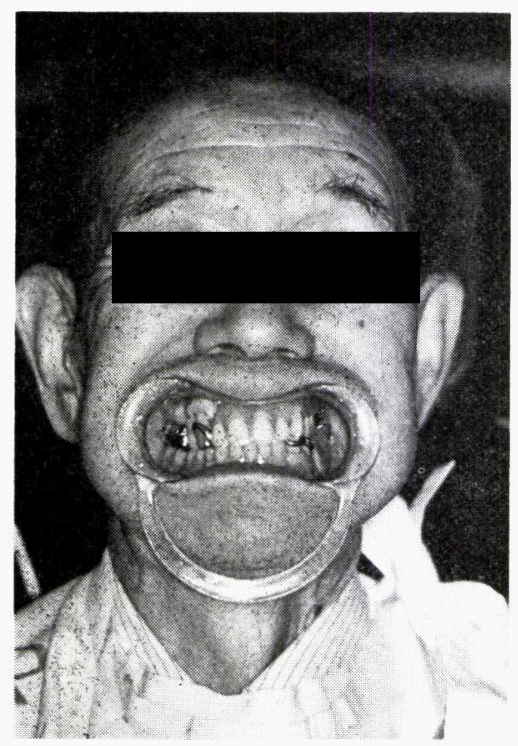

図 39 症例 2：術前所見

\section{IV 症例}

症例 1

患者は72歳の男性で，上下顎総義雨の不適合と 咀嚼時の床下粘膜部疼痛を主訴に来院した。 図35 に示すように顎堤の吸収が著しく，上顎ではとく に前方部と左側後方部の吸収が高度で左右非対称 


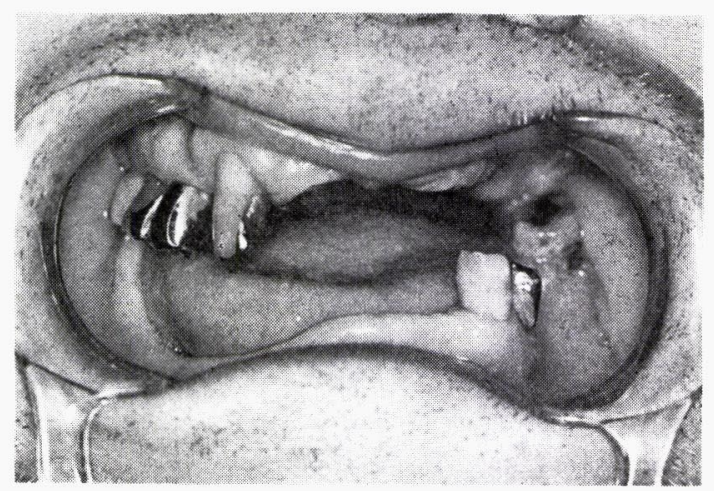

図 40 症例 2 : 術前の口腔内所見 左右的すれ違い校合である。

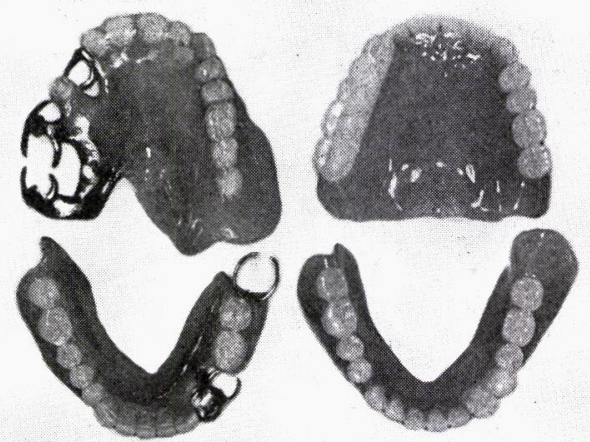

図 41 症例 2 ：左側に旧義雬, 右側に治療義雬 を示す.

性を呈している。下顎は全般的に高度の吸収状態 を示し，歯槽突起部は消失し前方部ではオトガイ 棘の方が高くなっている。治療にあたっては，リ ンガライズド・オクルージョン用ブレード・ティ 一スを用いて総義歯による補綴処置を施行した (図36)。咬合接触様式は, 著者らの提唱するリン ガライズド・オクルージョンである（図37）。術 前の患者の訴えは, 義歯が不安定で咀嚼時に義雨 が移動し, 特に下顎の顎堤に痛及が著明で, 硬い 食品は全く嚙めず，毎日扔粥ばかりすすっていた といらことであった。術後の患者の主観的評価 は, ビフテキやタクアンなど, 術前には食べるこ とをあきらめていた食品でも楽に食べられるよう になり，以前は憂うつであった家族や友人との食 事が何よりの楽しみになったとのことであった。 図38は, 術前と術後 1 力月に拈けるカマボュ咀嚼

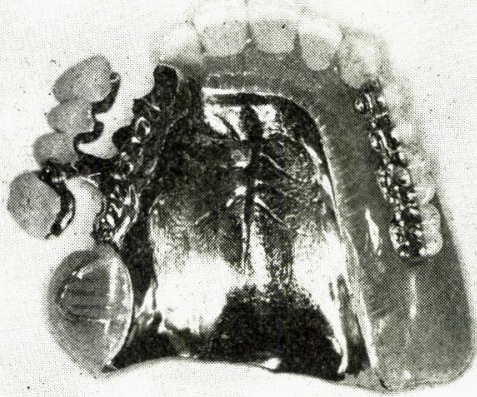

図 42 症例 2：上顎の最終義歯 リンガライズド・オクルージョン用ブレード・テ イースを応用。

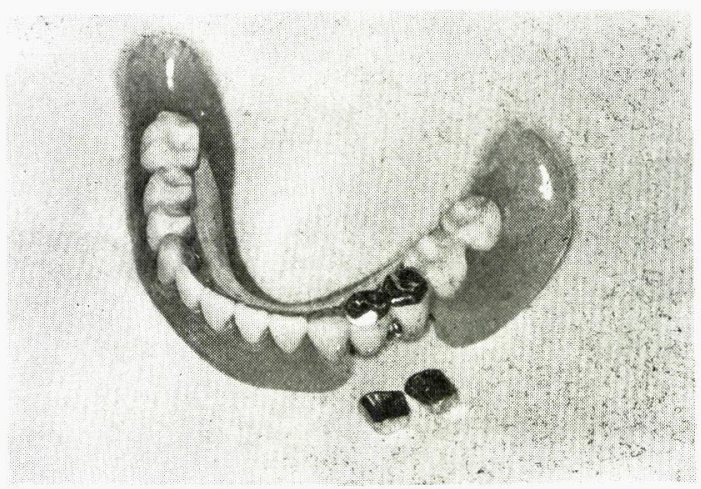

図 43 症例 2 : 下顎の最終義歯

支台装着としてコーヌス・クローネを応用。

時の MKG 記録で，前頭面に投影した下顎切歯 点の咀嚼運動経路（第 5～15 ストローク）を示し ている。術前に比べ, 術後 1 カ月では咀嚼運動経 路の改善傾向が認められ, 咀嚼がより円滑で, 咀 嚼パターンもチョッピングタイプに近付いてい る。予後は良好である。

\section{症例 2}

患者は82歳の男性で, 上下顎義歯の著明な動摇 と咀嚼ならびに発音障害を主訴に来院した（図 39). $76543 \mid$ と| 458 が残存するスレ違い咬合 で, 残存歯の挺出扣よび対合する欠損部顎堤の吸

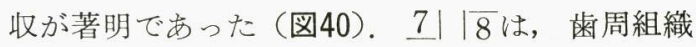
の破壊が進んで扣り, 保存不可能と診断し, 抜歯 処置を施行した，補緅処置にあたってはまず 図41に示す治療義米を製作し，顎位の修正とティ 


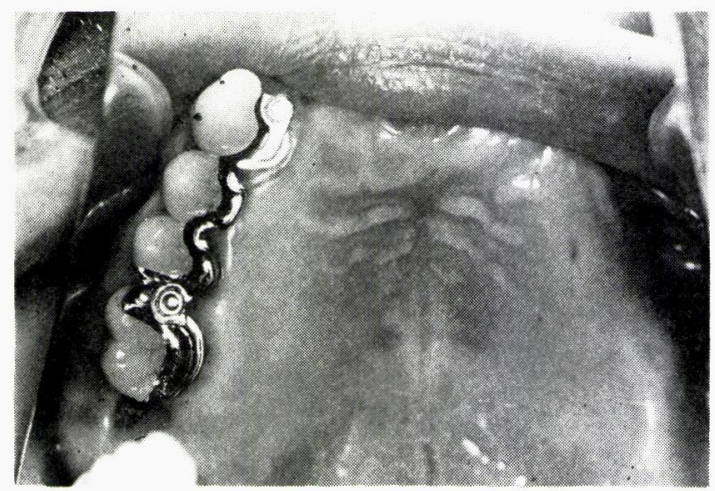

図 44 症例 $2: 6543 \mid$ はメタルボンドの連結冠とし た，維持装置として，パラレル・ミリングと コンビロック・アタッチメントを応用。

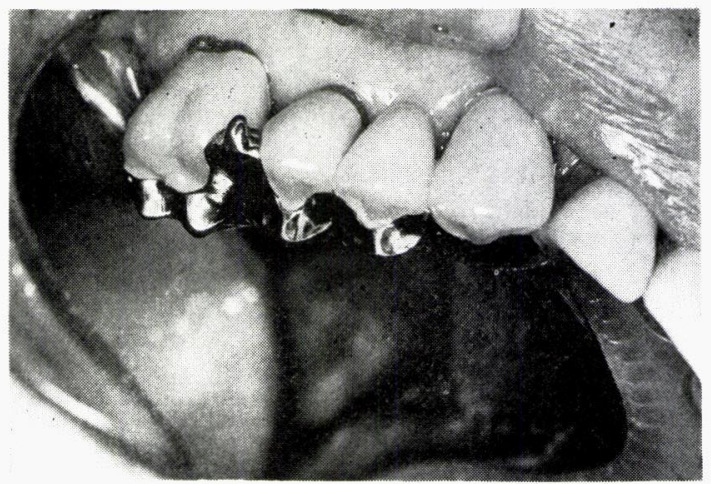

図 45 症例 $2: 6543$ の舌側咬頭は, すべてプレー ド・カスプとし金属休側に組み込んだ設計と した。

ッシュ・コンディンョニングを行った，治療義歯 は，上下顎ともにコースス・クローネ型とし，咬 合接触様式は解剖学的人工歯によるリンガライズ ド・オクルージョンとした。最終補綴処置では, パラレル・ミリングとコンビロック・アタッチメ ントを応用し，専用のブレード・ティースを用い て著者らの提唱するリンガライズド・オクルージ ョンを構成した（図42４7）， 6543| はメタルボン ドの連結冠とし，この部のブレード状の舌側咬頭 は，すべて金属床側に組み込んだ設計とした（図 42，44，45)。左右的スレ違い咬合は難症例とさ れているが，その最大の問題点は左右の支持能力 の差が著明であることで，劣っている欠損側の支 持能力をいかに補って機能を営ませるかが，設計 のポイントである。本症例では，まず欠損側の支

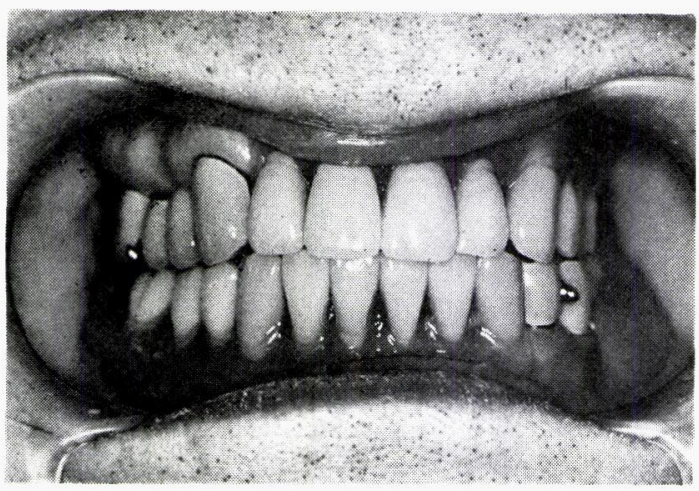

図 46 症例 $2:$ 術後の口腔内所見

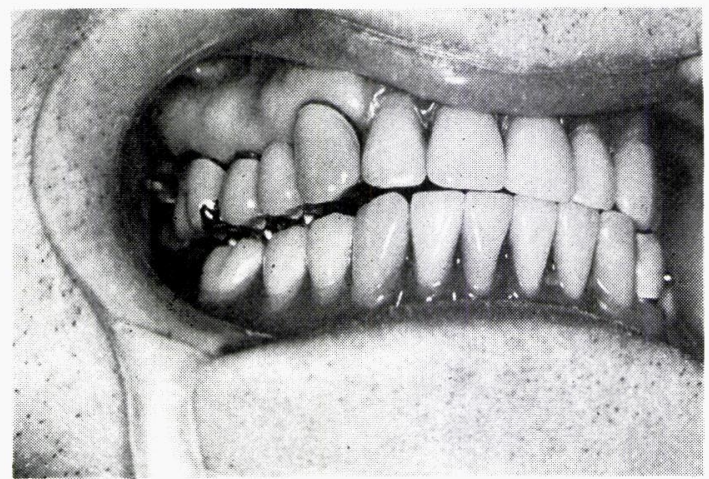

図 47 症例 2 : 咬合接触様式は著者らの提唱するリ ンガライズド・オクルージョンである.

持能力を最大限に引き出すため機能印象を行い可 及的に床面積を拡大した。 また，残存歯を連結冠 により連結固定したうえで，パラレル・ミリング と強固な大連結子により残存雪と床を一体化乙 て, 欠損側の劣っている支持能力を残存側で補 よらに設計した，次に咬合接触様式に関しても左 右的支持能力の差が問題になりにくいもの，すな わち, 小さな咬合力でも十分な機能が営めて義歯 床の安定性も良い咬合接触様式が望ましい。この ことから専用のブレード・ティースによるリンガ ライズド・オクルージョンが最適であると考党 た。図48は術前, 治療義歯装着後 1 力月, そして 最終補経処置終了後 1 力月の $M K G$ 記録を示し ている. いずれもピーナッッ咀嚼で第 5〜15 ス卜 ロークを示して和り，術前に比べて治療義歯装着 


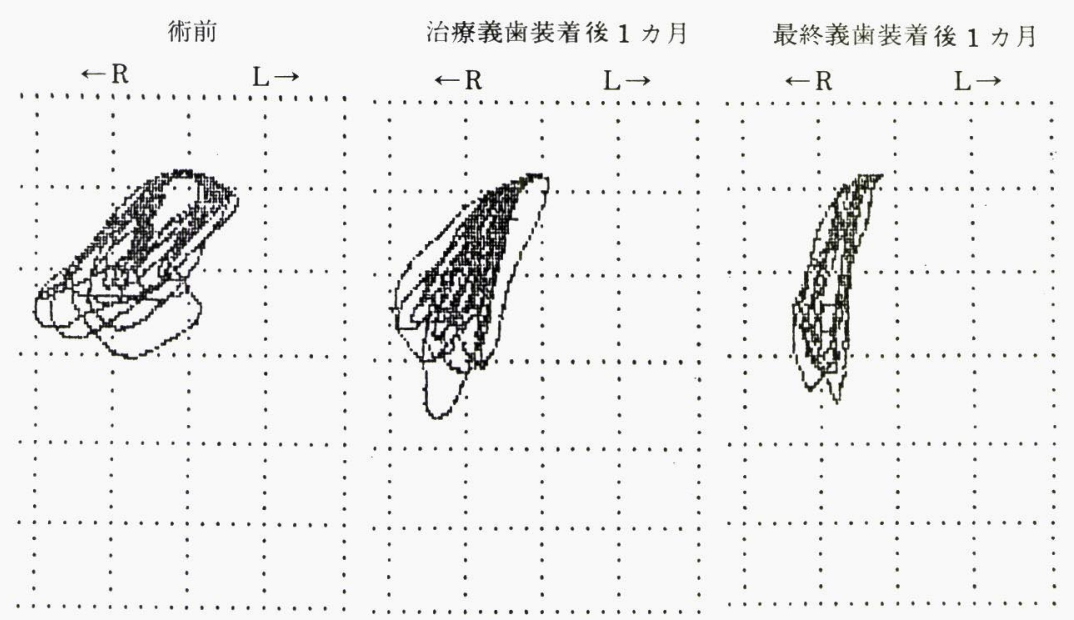

図 48 症例 $2:$ 術前, 治療義歯装着後 1 力月, そして最終義歯装着後 1 力月に呫 ける咀嚼運動経路記録（前頭面投影・第 5 ～15 ストローク）

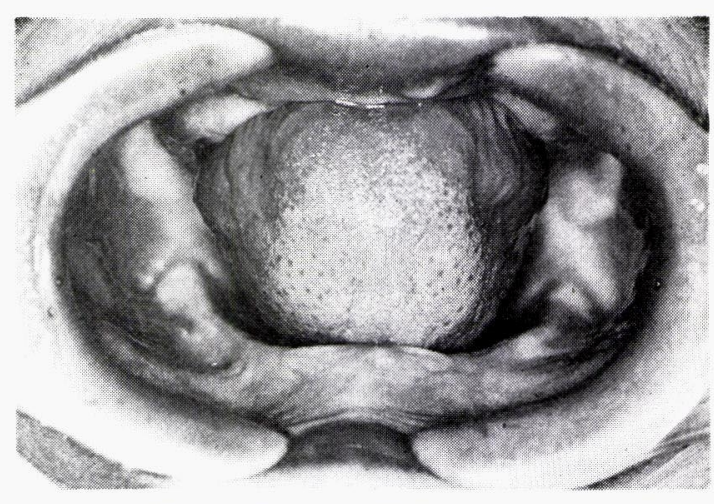

図 49 症例 3 : 術前の口腔内所見

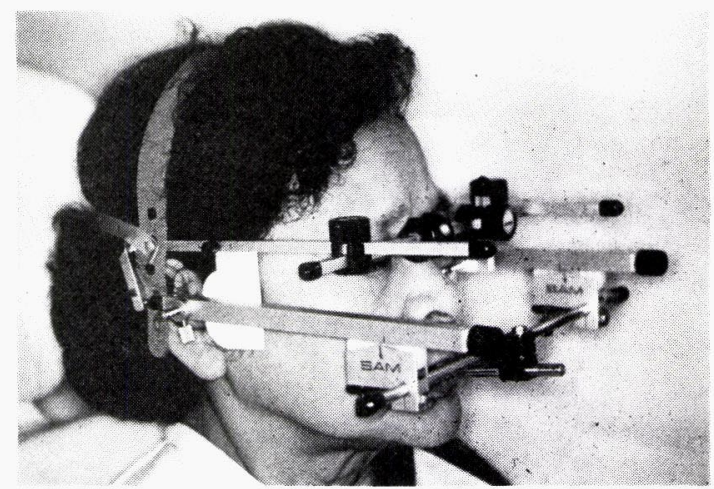

図 50 症例 3 : Simplified condylar movement recorder による顎機能診査と下顎頭位の 確認.

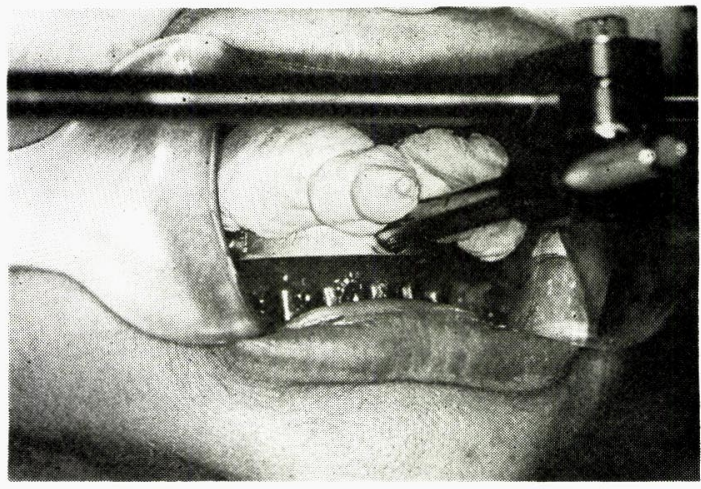

図 51 症例 $3:$ Simplified condylar movement recorder により下顎頭位を確認しながら チェックバイトを行う。

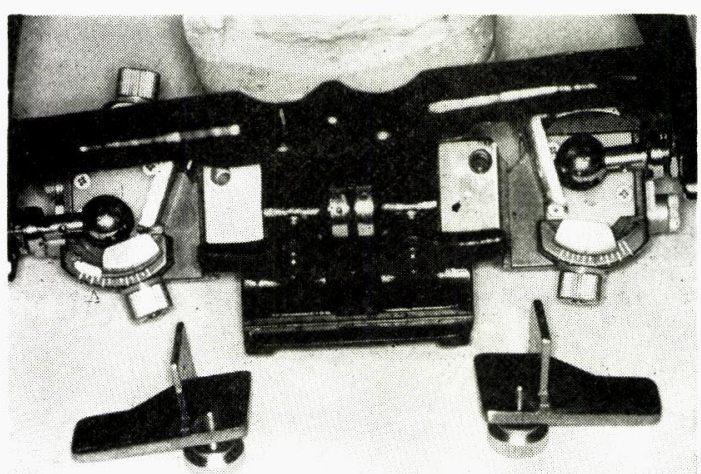

図 52 症例 3 : プロソマチック咬合器を使用して, 作業側と平衡側顆路の調節を行う。 


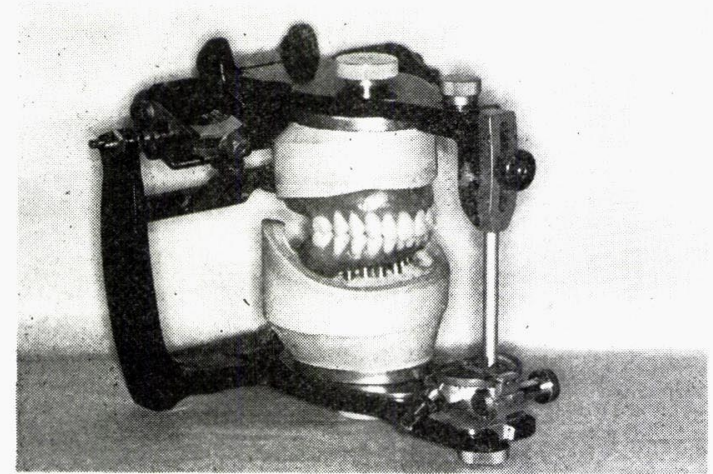

図 53 症例 $3 ：$ 口義歯完成

著者らは，下䫇運動の誘導に直接関与する補経物 の製作にあたっては常時, 著者らの開発したプロy マチック咬合器 (高宮歯科工業社製) を使用してい ๖.

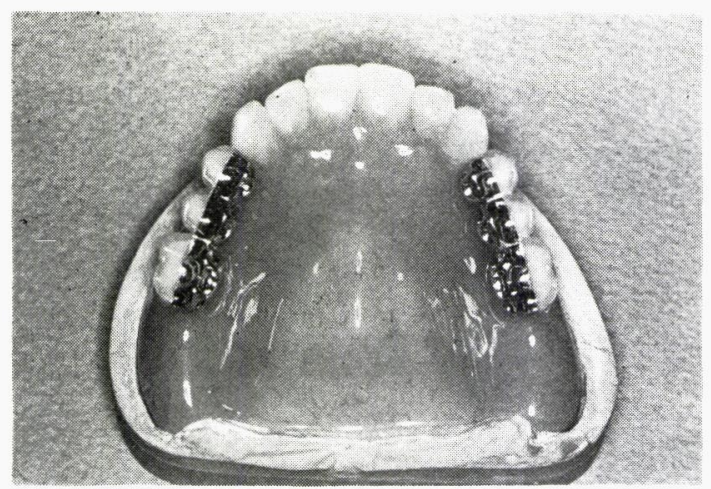

図 54 症例 $3:$ 完成した上㴿総義歯

リンガライズド・オクルージョン用ブレード・テ イースを応用。

後 1 カ月では, 咀嚼パターンの規則性の向上が認 められ, 最終補綴終了後 1 力月では, さらに規則 性が向上し, 咀嚼パターンはチョッピング・タイ プに近付いている。術後に打ける患者の主観的評 価は，「食べることをあきらめていた肉，フラン スパン，漬物など，何でも20年ぶりにしっかりと 食べられるよらになった。食べることが楽しくて しょらがない」と述べて扣り，発音障害も全く認 められず，十分満足している. 予後は良好である.

\section{症例 3}

患者は67歳の女性で, 上下顎総義霜の安定不 良, 下顎義歯床下粘膜の疼痛, 咀嚼障害を訴えて 来院した. 特に下顎の顎堤吸収が著明で, 咀嚼時

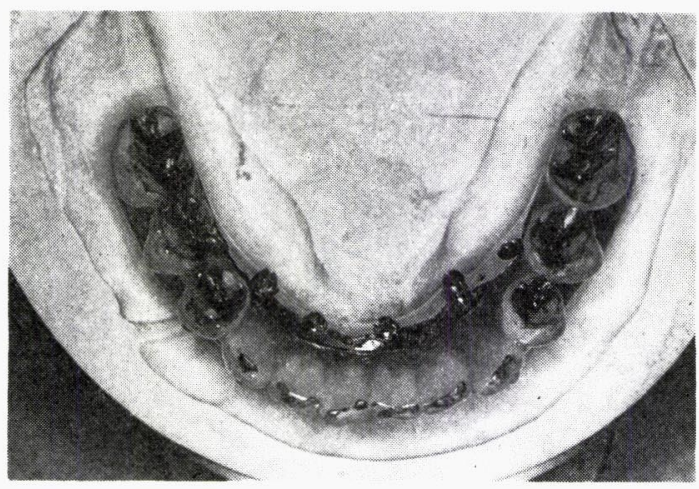

図 55 症例 $3:$ 咬合器上で咬合調整操作中の下顎 インプラント・ブリッシ

咬合接触様式は著者らの提唱するリンガライズ ド・オクルージョンを構成し, 最終的に咬合誘導簌 囲は上顎第 1 大臼歯近心舌側咬頭までとした.

の下顎義歯床下組織の疼痛のため, 泀とんど何も 嚙むことができず，丸飲みにしている状態であっ た（図49）。治療にあたっては，上下顎の総義茵 を新たに製作し，解剖学的人工歯を用いて著者ら の提唱するリンガライズド・オクルージョンを構 成した。審美性，発音，ならびに上顎総義歯の安 定性に関しては良好な結果が得られたが，下顎総 義歯では高度の骨吸収のためオトガイ孔が下顎歯 槽頂上に開口して未り，低然として疼痛を訴えて いた，骨吸収が高度であるら党に，左右のオトガ イ孔部を広くリリーフしなくてはならなかった ため，十分な支持領域が得られないら省義歯床 の辺縁封鎖が保てず，結果的に下買義歯の安定性 不良と床下組織の疼痛による咀嚼障害が依然とし て認められた。 そこで, 患者の希望もあり, 一連 の診査を行ったところ条件を満たしていたことか ら，オッセオインテグレーテッド・インプラント による咬合再建処置を施行することとした。下顎 は 6 本のフィクスチャーを応用したインプラン ト・ブリッジ（スクリューオン・デンチャー）, 上顎は総義歯とした。フィクスチャーへの負担軽 減のためには，顎機能に調和した咬合の付与が不 可欠であるため, simplified condylar movement recorder ${ }^{28,29)}$ により下頢頭位を確認しながらチェ ック・バイト記録を行った(図50，51）。次いで著 者らの開発したプロソマチック咬合器30-32) を使 用して平衡側と作業側の顆路調節を行ったらえで 


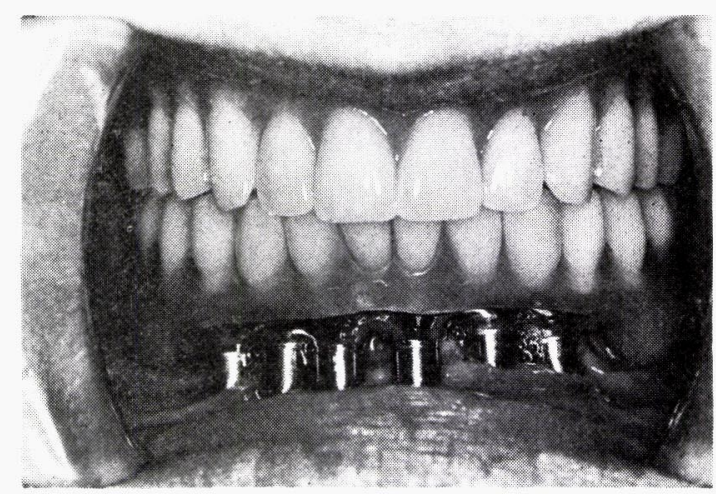

図 56 症例 3 : 術後の口腔内所見

咬合構成にとりかかった（図52，53）。フィクス チャーヘの負担軽減の目的から, 専用のブレード ・ティースを用いてリンガライズド・オクルージ ヨンを構成し（図54，55），最終的に咬合誘導範 囲は上顎第 1 大臼米近心舌側咬頭までとし，遠心 舌側咬頭は，中心咬合位でのみ対合歯と咬合接触 させ，偏心位ではディスクルージョンさせた（図 56).

図57は, 2 次手術終了後の治療義朄装着時と, インプラント・ブリッジ装着後 1 カ月に扣ける $\mathrm{MKG}$ 記録である。いずれも前頭面に捺ける咀嚼 経路の第 5～15 ストロークを示しており，最終補 綴処置後, 著明な改善傾向を示し, 咀嚼パターン はチョッピング・タイプに近付いている．患者に よる術後の主観的評価は，「術前，食べたいが食 ベられなかった食品が，すべて食べられるように なり，痛みも全くなくなった。十分に満足してい る」とのことであった。

\section{V ま と め}

高歯化社会から高柃社会へと移り，有床義歯に よる欠損補経の果たす役割りはさらに大きい。著 者らは, 有床義幽による治療の成否に大きな影響 を及ぼを考えられる咬合接触様式に関して，一 連の基礎的ならびに 臨床的研究をつづけてきた が，現時点までに得られた知見に基ついて，残存 組織保全と機能回復率向上の両立性の観点から, 客観的に最も有利な咬合接触様式のあり方を探究 した結果，本稿で示した条件のリンガライズド・
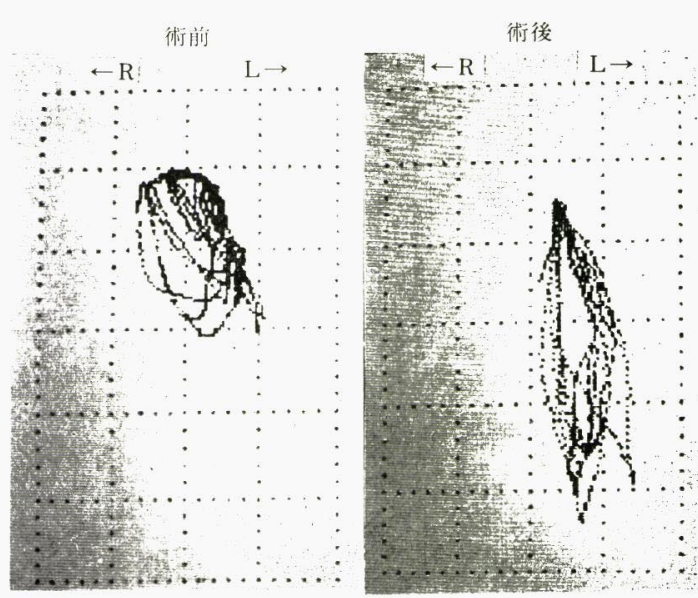

図 57 症例 $3: 2$ 次手術終了後の治療義歯装着時 (術前) とインプラント・ブリッジによる最 終補経終了後 1 力月に扣ける咀嚼運動経路記 録（前頭面投影・第 5 1 15 ストローク）

オクルージョンが最も有効性に優れ，有利な咬合 接触様式であるといら結論に達した。 また，著者 らの提唱するリンガライズド・オクルージョンの 長所をさらに増強するために，人工雪の咬合面形 態はいかにあるべきかを探究し，これまでのまと めを臨床例とその臨木成績も交えて報告した。こ れらは, あくまでも現時点での研究経過報告であ り，有床義歯の咬合接触様式は奥が深い、今後も 引き続き研躦を積んで行く所存である。

\section{参考文献}

1）小林義典, 中野幸夫, 曾根崎利雅, 他 : 総義歯に 関する臨床調查 第 1 報。歯学 70: 776, 1982 .

2）児玉秀夫，稻富健祐，秋山克也，他：総義歯に関 する臨床調查 第 2 報 顎堤の状態（その 1 ） 嚬堤吸収の程度について。歯学 73: 1365-1366, 1985.

3）児玉秀夫，稻富健祐，岩波行紀，他：総義歯に関 する臨床調査 第 3 報 顎堤の状態 (その 2) 顎是の形態执よび歯慒頂間線角度について．歯学 73: 1386-1387, 1985.

4) 山崎 勉, 小此木富美子, 稲富健祐, 他 : 総義歯に

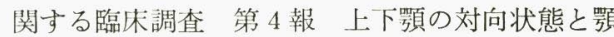
是吸収状態との関係。来学 76：1080-1081, 1988.

5) Gysi, A.: Handbuch der Zahnheikunde (IV Band). Scheff Pichler, Berlin, Urban \& Schwarzenberg, 1929.

6) Payne, S Howard: A posterior, set-up, to meet individual requirements. The Dental Digest 20-22, 1941. 
7) Pound, E.: Utilizing speech to simplify a personalized denture service. J Prosthet Dent 26: 586-600, 1970.

8) Pound, E, et al.: An introduction to denture simplification. J SO Calf Dent Assn 33: 990999, 1971.

9) Pound, E.: An Introduction to Denture Simplification. J Pros Dent 29: 598-607, 1973.

10) Gerber, A, Steinhardt, G.: Kiefergelenkstörungen-Diagnostik und Therapie. Quintessence Verlags-GmbH, 1st ed, Berlin, 1983.

11）小出 馨：総義歯の咬合接触様式に関する実験的 研究. 歯学 72(2)：231-265, 1984.

12）西野和之,八子誠一郎, 旗手 敏: 局部床義歯の 咬合接触様式に関する実験的研究. 㮀学 73(2): 179-225, 1985.

13）小野兼義，旗手 敏：有休義歯に付与する咬合接 触様式に関する研究一Lingualized Occlusion が 咀嚼機能に及ぼす影響について一。歯学 76(1): 107-137, 1988.

14）小出 㢣：リンガライズド・オクルージョンは何 故優れているか（鈎歯保全と咀嚼効率を考虑した 咬合接触様式の選択)。ザ・クインテッセンス 15(9): 107-119, 1986.

15）小出 檠：リンガライズド・オクルージョンの生 かし方（上）一理論と術式一, QDT 12(9)：3649, 1987.

16）小出 整：リンガライズド・オクルージョンの生 かし方（下）一症例に応じた使い分けとリンガラ イズド・オクルージョン用ブレード・ティー スー, QDT 12(10): 65-83, 1987.

17）岡村敏弘, 粸手 敏, 渡辺 毅 : 下顎遊離端義歯 に対合する上顎恔合面形態に関する考察 第 1 報 臨床例および臨床的評価, 畨学 78: 170, 1990.

18）岡村敏弘, 小出 㢣, 旗手 敏 : 有休義歯に付与 する咬合接触様式に関する研究 第14報 リンガ ライズド・オクルージョンの臨床応用法, 補経 誌, 34巻83回特別号 130, 1990.
19）旗手 敏：局部床義歯に付与するリンガライズ ド・オクルージョン，その有効性。歯科ジャーナ ル 32(6): 517-525, 1990.

20) 小出 㢣：リンガライズド・オクルージョン，歯 科ジャーナル 32(6): 627-642, 1990.

21) Sosin, M.B.: Re-evaluation of posterior tooth forms for complete dentures. J Prosthet Dent 11: 55-61, 1961.

22) 阿部晴彦: Bladed metal teeth technique, 補経 臨床 2: 281-287, 1969.

23）阿部晴彦: 総義歯と Bladed metal teeth, 歯科臨 㦿技術講座，医歯薬出版，東京，711-732，1971.

24）阿部晴彦泳か：排列の実際; Bladed metal teeth の排列, 補経臨床 6: 287-291, 1973.

25) Levin, B.: A View of Artificial Posterior Tooth Forms including a Preliminary Report on a New Posterior Tooth, J. Pros. Dent. 38: 315, 1977.

26）岡村敏弘，粸手 敏：SAM 社製 Axiograph を用 いた顎関節症の診查・診断・治療 (5・完), 日本 歯科評論 581: 175-200, 1991.

27）児玉秀夫：舌房の侵害が顎管活動に及ぼす影響。 歯学 65: 1008-1042, 1978.

28）岡村敏弘, 小出 馨, 旗手 敏 : 顎関節内障に関 する臨床的研究 第 2 報 下顎頭運動経路の変化 について。補経誌 31: 1280，1987.

29）岡村敏弘，旗手 敏：䪽関節内障に批ける下顎頭 の回転と滑走に関する二軸描記法による臨床的研 究. 補経誌 33: 1359-1373, 1989.

30）小出 馨, 永田和裕, 粸手 敏: ツインプレート 機構を備えたアルコン型半調節性咬合器に関し て (第 1 報)。歯学 74(4): 922-923， 1986.

31）永田和裕, 小出 警, 旗手 敏：ツインプレート 機構に備えたアルコン型半調節性咬合器に関して （第 2 報）。粀学 74(3)：674-675，1986.

32) 小出 憼, 永田和裕, 旗手 敏: ツインプレート 機構を備えたアルコン型半調節性咬合器に関して (第 3 報)。補経誌 31：528，1987. 